\title{
BLISTER CANKER OF APPLE TREES A PHYSIOLOGICAL AND CHEMICAL STUDY
}

\author{
A DISSERTATION \\ SUBMITTED TO THE FACULTY \\ OF THE OGDEN GRADUATE SCHOOL OF SCIENCE \\ IN CANDIDACY FOR THE DEGREE OF \\ DOCTOR OF PHILOSOPHY \\ DEPARTMENT OF BOTANY \\ BY \\ DEAN HUMBOLDT ROSE
}

Private Edition, Distributed By

THE UNIVERSITY OF CHICAGO LIBRARIES

CHICAGO, ILLINOIS

Reprinted from

The Botanical Gazette, Vol. LXVII, No. 2

February I9I9 



\title{
BLISTER CANKER OF APPLE TREES; \\ A PHYSIOLOGICAL AND CHEMICAL STUDY
}

\author{
A DISSERTATION \\ SUBMITTED TO THE FACULTY \\ OF THE OGDEN GRADUATE SCHOOL OF SCIENCE \\ IN CANDIDACY FOR THE DEGREE OF \\ DOCTOR OF PHILOSOPHY \\ DEPARTMENT OF BOTANY
}

BY

DEAN HUMBOLDT ROSE

Private Edition, Distributed By

THE UNIVERSITY OF CHICAGO LIBRARIES

CHICAGO, ILLINOIS

Reprinted from

The Botanical Gazette, Vol. LXVII, No. 2

February I9I9 
SB608

. 4677

Gir
Autlad
MAR 131919 


\title{
T H E
}

\section{Botanical Gazette}

\author{
FEBRUARY IOI9
}

BLISTER CANKER OF APPLE TREES; A PHYSIOLOGICAL AND CHEMICAL STUDY

CONTRIBUTIONS FROM THE HULL BOTANICAL LABORATORY 246

DEAN H. ROSE

(WITH TEN FIGURES)

\section{Introduction}

It is now generally recognized that among the most important problems of plant pathology are those connected with the physiology of diseases whose etiology is already known. It is also recognized that this must be the physiology of the host, of the parasite, and of the two in relation to each other, and, further, that such a comprehensive view of all the factors involved furnishes the only rational approach to an understanding of the principles underlying immunity and disease resistance.

In the present paper are given the results of a physiological study of the destructive disease known as Illinois or blister canker, the etiology of which, including the identity of the causal organism, Nummularia discreta (Schw.) Tul., was worked out by HAsseLBRING (22) in I902. The work reported here is a continuation of an earlier investigation by the writer (30) on the oxidase activity of healthy and diseased bark; in addition there is included an account of the catalase activity and microchemical and macrochemical analyses of both kinds of tissues. Further work is planned on the chemistry of the disease, on the rôle of other enzymes than oxidases, and on the physiology of the fungus itself in pure culture. 
The work was done in part at the Missouri State Fruit Experiment Station and in part in the Botany Department of the University of Chicago.

\section{Historical}

The problem of oxidation by plant and animal tissues or tissue extracts has been studied by many investigators since the time of the pioneer work by SchönBEIN, the discoverer of ozone. An immense literature has accumulated, for reviews of which the reader is referred to publications by Clark (14), Kastle (24), Battelli and Stern (5), and Atkins (3). In this paper only those articles will be cited which bear directly on the problem in hand.

That pathological conditions in plants are often accompanied by increased oxidase activity has been shown repeatedly in recent years. Woods (35) found greater oxidizing power in the chlorotic portions of tobacco leaves affected with mosaic than in the green portions; this has been confirmed by AlLARD (I) and by FREIBerg (20). Sorauer $(3 \mathbf{1}, 32)$ and Doby (17), working with leafroll of potatoes, found oxidase activity greater in diseased tubers than in healthy ones, although the former makes the point that this greater enzyme activity is to be considered a symptom of the disease rather than the cause. BunzeLL (II), working with the curly-dwarf disease of potatoes, showed by an extensive series of tests that "affected plants have a greater oxidase activity than healthy ones of the same age, both in the juice of their tubers and in the juice of their foliage." Similar results were obtained by Bunzell (ro) in work with curly-top of sugar beets. All 4 of these diseases are of the so-called physiological type, and the question is still unsettled for the last 3 whether the increased oxidase activity is the cause of the disease or merely the result of disturbances due to the real but at present unknown cause.

In the case of diseases whose cause is known the oxidase situation seems to be about the same as for those already mentioned. REED (29) found that the juice of apples affected with bitter rot (Glomerella cingulata) has greater oxidase activity than that of sound apples. In his previous work the writer (30) found that diseased apple bark shows greater oxidase activity than healthy bark, and is at the same time less acid. This seems to indicate 
that the oxidizing power of a tissue bears some relation to its acidity, a relation which was rendered more probable by the fact that, according to titration and indicator tests, the acidity rises in the Bunzell apparatus during the course of an experiment at the same time that oxidation gradually decreases and finally ceases. The suggestion was made, therefore, that "the gradual slowing down of oxidation in the Bunzell apparatus is brought about in part by the accumulation of oxidation products, probably acetic and oxalic acids in the case of pyrogallol, and not by a using up of the oxidase through chemical combination between oxidase and oxidizable substance." The validity of this theory in the light of later investigation will be discussed in the experimental part of this paper.

\section{Experimental}

\section{OXIDASE ACTIVITY}

EXTRACTS OF FRESH BARK.-An account will first be given of that part of the work done at the Missouri State Fruit Experiment Station. Extracts of fresh Ben Davis bark were used, prepared as follows: limbs were brought in from the orchard, the bark quickly ground in a meat grinder, and water and toluol added in the proportion of $4.25 \mathrm{cc}$. of toluol for each $100 \mathrm{cc}$. of water. The mixture was then allowed to extract at $28-30^{\circ} \mathrm{C}$. for I hour, with frequent stirring, and filtered through filter paper. The proportions of water and toluol used, assuming that the fresh bark contained $5^{\circ}$ per cent water, were such as to make the extracts very nearly equivalent to those prepared for the earlier work (30) with dried bark. All data were corrected to the basis of dry weight determined by weighing and drying samples of the ground bark in triplicate to constant weight in a bath at $95^{-} 99^{\circ} \mathrm{C}$.

Measurement of the amount of oxidation was made by means of the simplified Bunzell apparatus, using I cc. of the extract prepared as just described, and either $4 \mathrm{cc}$. of a I per cent solution of pyrogallol, $0.04 \mathrm{gm}$. of benzidine, or 2 drops $(0.025 \mathrm{gm}$.) of guaiacol; water was added to make the final volume $6 \mathrm{cc}$. The various combinations of bark, oxidase reagent, and water were run in duplicate. 
After the experiment had been set up in the incubator, I hour was allowed for the apparatus and solutions to come to a constant temperature. The manometers were then closed and the solutions mixed. No shaking machine was used, but the apparatus holder was tipped back and forth several times whenever a reading was taken. Allowance for temperature variations was made by running with each experiment a blank containing only water and correcting the others by it.

Table I gives the results of two representative experiments, showing the amount of oxidation of the 3 different reagents by

TABLE I

OXIDATION OF PYROGALLOL, BENZIDINE, AND GUAIACOL BY EXTRACTS OF HEALTHY AND DISEASED BARK; MANOMETER READINGS CORRECTED AGAINST APPARATUS CONTAINING ONLY WATER; TEMPERATURE $28-3 \mathrm{I}^{\circ} \mathrm{C}$.

\begin{tabular}{|c|c|c|c|c|c|c|c|c|}
\hline \multirow{4}{*}{$\underset{\text { TEST }}{\text { DAX OF }}$} & \multicolumn{6}{|c|}{ EXTRACT OF FRESH BARK } & \multirow{2}{*}{\multicolumn{2}{|c|}{$\begin{array}{c}\text { EXTRACT OF DRIED } \\
\text { BARK } \\
\text { Pyrogallol }\end{array}$}} \\
\hline & \multicolumn{2}{|c|}{ Pyrogallol } & \multicolumn{2}{|c|}{ Benzidine } & \multicolumn{2}{|c|}{ Guaiacol } & & \\
\hline & Healthy & Diseased & Healthy & Diseased & Healthy & Diseased & Healthy & Diseased \\
\hline & Sample $38 a$ & Sample $38 b$ & Sample $4 \mathrm{r} a$ & Sample ${ }_{4} \mathrm{I} b$ & Sample $38 a$ & Sample $38 b$ & & \\
\hline I.... & 0.0 & 0.0 & 0.0 & 0.0 & 0.0 & 0.0 & 0.0 & 0.0 \\
\hline $2 \ldots$ & $0.7 \mathrm{I}$ & I. 62 & 0.17 & 0.82 & 0.02 & 0.43 & 0.26 & 0.57 \\
\hline $3 \ldots$ & I. 38 & 2.46 & 0.22 & I. 2 I & O.II & I. I6 & 0.53 & 0.94 \\
\hline $4 \ldots$ & I. 70 & 2.50 & $0.4 \mathrm{I}$ & I. 76 & $0.2 \mathrm{I}$ & I. 38 & 0.77 & I. 20 \\
\hline & I. 83 & $2 \cdot 50$ & 0.50 & 2.07 & 0.27 & I. $5 \mathrm{I}$ & 0.86 & I. 36 \\
\hline $6 \ldots$ & $\ldots \ldots$ & 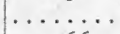 & $\ldots \ldots$ & $\ldots \ldots$ & $\ldots \ldots$ & $\ldots$. & I. 07 & I. 50 \\
\hline $7 \ldots$ & 2.12 & 2.66 & 0.60 & $2 \cdot 3 I$ & 0.32 & I. 68 & $\ldots$ & $\ldots \ldots$ \\
\hline $8 \ldots$. & 2.20 & 2.73 & 0.74 & $2.5^{2}$ & 0.32 & I.9I & $\ldots \ldots \ldots$ & $\ldots \ldots$ \\
\hline $9 \ldots$ & $2 \cdot 36$ & 2.86 & 0.77 & 2.67 & 0.35 & I. 98 & $\ldots \ldots \ldots$ & $\ldots \ldots$ \\
\hline 10..... & 2.44 & 2.96 & 0.88 & 2.93 & $0.4^{2}$ & 2. 18 & I. $5^{I}$ & I. 94 \\
\hline Ratio.. & $\mathrm{I} . \infty \mathrm{tc}$ & Io I. $2 \mathrm{I}$ & $1.00 \mathrm{tc}$ & to 3.32 & $1.00 \mathrm{t}$ & to 5.19 & $\mathrm{I} .00 \mathrm{t}$ & 0 I. 28 \\
\hline
\end{tabular}

extracts of both healthy and diseased bark. There are included also data from the earlier paper showing the amount of oxidation of pyrogallol by extract of dried bark. The results indicate that for approximately equal amounts of dry matter the dried bark is considerably less active than the fresh (fig. I). The decrease is probably due to the drying; this is shown more definitely by data to be presented later. It is to be noted that the oxidase activity of diseased bark is definitely greater than that of healthy bark, 
although the ratio between the two is greater where benzidine or guaiacol was used as oxidase reagent than where pyrogallol was used. The writer prefers to follow Bunzell in using the term oxidase activity or oxidizing power rather than "oxidase." Where the latter term occurs in this paper, it is used only for the sake of brevity, with no intent to imply any fixed notion as to the nature of the agent which brings about the oxidation.

Titration and indicator tests on extracts of fresh bark showed the healthy bark to be more acid than the diseased, exactly as had been shown previously in the work with dried bark. No data

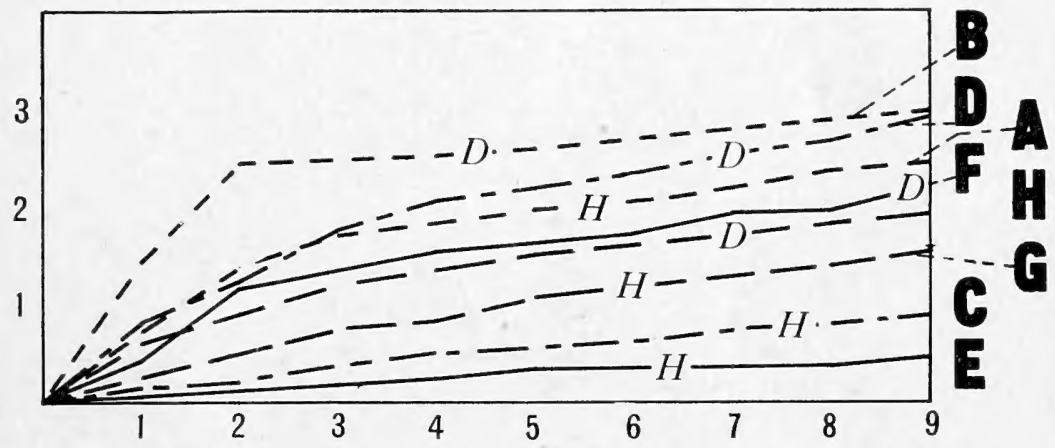

FIG. I.-Oxidation of pyrogallol, guaiacol, and benzidine by extract of fresh bark, healthy and diseased, and extract of dried bark, healthy and diseased: A, pyrogallol and fresh healthy bark; B, pyrogallol and fresh diseased bark; C, benzidine and fresh healthy bark; D, benzidine and fresh diseased bark; E, guaiacol and fresh healthy bark; F, guaiacol and fresh diseased bark; G, pyrogallol and dried healthy bark; $\mathrm{H}$, pyrogallol and dried diseased bark; $H=$ healthy, $D=$ diseased.

are given, since the true condition, at least for dried bark, was determined more accurately by means of a potentiometer.

EXTRACTS OF DRIED BARK.-For the work at the University of Chicago bark was used which had been dried at $35-40^{\circ} \mathrm{C}$. for 2-3 hours, ground fine enough to go through a 40-mesh sieve, and stored air dry in zinc-capped Mason jars. A few of the experiments were run with oxidases precipitated from an extract of this bark powder, but in most of them the powder itself was used, o. Io gm. in each apparatus. The reagents tested were pyrogallol and pyrocatechin, 4 cc. of a I per cent solution; benzidine $0.05 \mathrm{gm}$.; 
guaiacol 2 drops $(0.025 \mathrm{gm}$.). Tests for any given set of conditions were always run in duplicate, sometimes in triplicate, or even quadruplicate. All experiments were shaken for 3 hours at the rate of ro6 complete excursions per minute in a constant temperature chamber provided with a fan driven from the outside, and then allowed to stand for 10-90 hours. Temperature variations were rarely greater than $0.5^{\circ}$ during the shaking period, but sometimes amounted to as much as I $.0^{\circ}$ afterward, owing to less perfect control when the machinery was not in motion. Corrections for temperature variations were made as before by comparison with a blank containing only water.

Potentiometer measurements were made with a hydrogen electrode like that described by BovIE (8), streaming hydrogen, 3 resistance boxes as described by Michaelis (25, p. I3I), a saturated calomel electrode, a normal element checked against another which had been calibrated by the United States Bureau of Standards, and a Leeds and Northrup dead-beat galvanometer. Hydrogen of high purity from a tank of the compressed gas was run through an electrically heated combustion tube containing platinized asbestos and then through the hydrogen electrode tube. The latter, together with the capillary from the calomel electrode, projected through a rubber stopper into the vessel containing the solution to be tested. Escape of hydrogen was provided for by a third opening in the stopper. An error was undoubtedly introduced here, due to displacement of $\mathrm{CO}_{2}$ from the solution, in cases where the hydrogen ion concentration was less than $\mathrm{IO}^{-5}$ (Michaelis, pp. I42-I44), but since the only solutions showing this slight degree of acidity were mixtures of bark, water, and pyrogallol for determination of hydrogen ion concentration before any oxidation had taken place, and since all others were found to be more acid, the error is probably negligible. It could have been avoided entirely by using a Hasselbalch shaking electrode had it and the time for using it been available.

Among the first experiments run was one designed to test fully the oxidase activity of healthy and diseased bark when pyrogallol was used as the oxidizing substance. The results, given in table II, are the average of 5 closely agreeing determinations. These results 
agree well with those obtained without a shaking machine in showing considerably greater oxidation by diseased than by healthy bark. The ratio between the two, I.00:2. I9, is larger than that found previously ( $1.00: 1.28$ ), the difference probably being due to differences in drying or possibly to the shaking itself.

TABLE: II

OXIDATION OF PYROGALLOL BY HEALTHY AND DISEASED APPLE BARK; SAMPLES 3 AND 4 ; TeMPeratURe $27 \mathrm{C} \pm \mathrm{I} .7^{\circ} \mathrm{C}$.

\begin{tabular}{|c|c|c|c|c|c|}
\hline \multirow[t]{2}{*}{$\begin{array}{l}\text { Time of } \\
\text { READing }\end{array}$} & \multicolumn{2}{|c|}{$\begin{array}{l}\text { MANOMETER READINGS, EX- } \\
\text { PRESSED IN CM. OF MERCURY, } \\
\text { CORRECTED AGAINST BLANK } \\
\text { CONTAINING ONLY WATER }\end{array}$} & \multirow[t]{2}{*}{$\begin{array}{l}\text { TIME OF } \\
\text { READING }\end{array}$} & \multicolumn{2}{|c|}{$\begin{array}{l}\text { MANOMETER READINGS, EX- } \\
\text { PRESSED IN CM. OF MERCURY, } \\
\text { CORRECTED AGAINST BLANK } \\
\text { CONTAINING ONLY WATER }\end{array}$} \\
\hline & Healthy & Diseased & & Healthy & Discased \\
\hline March I9 & & & March Io & & \\
\hline $2: 45$ P.M..... & 0.0 & 0.0 & March I9 & 0.48 & I. 25 \\
\hline $3: 00 \ldots \ldots$ & 0.0 & $\begin{array}{l}0.23 \\
0.48\end{array}$ & $\begin{array}{l}4: 45 \text { P.M.... } \\
5: 00 \ldots\end{array}$ & 0.53 & I. 33 \\
\hline $3: 15 \ldots$ & 0.10 & 0.48 & $5: 00 \ldots \ldots$ & 0.01 & I. 45 \\
\hline $3: 30$ & 0.16 & 0.05 & $\begin{array}{l}5: 15 \ldots \ldots \\
5: 30 \ldots\end{array}$ & 0.04 & I. 57 \\
\hline $3: 45$ & 0.23 & 0.80 & $5: 30 \ldots \ldots$ & 0.59 & 1.49 \\
\hline $4: 00 \ldots$ & $0.3 \mathrm{I}$ & 0.92 & $\begin{array}{l}5: 55 \ldots \ldots \\
\text { March } 20\end{array}$ & & \\
\hline $4: 15 \ldots \ldots \ldots$ & $0.4 \mathrm{I}$ & 1.05 & $8: 30 \mathrm{~m}$ & 1.10 & 2.41 \\
\hline $4: 30 \ldots \ldots$ & 0.45 & I. I I & $8: 30$ A.M1... & & \\
\hline
\end{tabular}

In table III are summarized the results of an experiment to test the oxidizing power of both diseased and healthy bark on pyrocatechin, guaiacol, and benzidine.

A comparison of the figures in table III with those in tables I and II shows that diseased bark causes greater oxidation of pyrogallol, pyrocatechin, benzidine, and guaiacol than does healthy bark, and that both tissues cause greater oxidation of the first two reagents than of the last two. It is further shown by tables I and III that the amount of oxidation increases slowly for several days; in fact table III shows that it is practically doubled for all the combinations, except those containing pyrocatechin, during the 64-hour period following the 3 hours' shaking. This fact of an increase of oxidation on standing was observed to a greater or less degree with most of the bark material used in this work, and is in direct contradiction to BunzeLI's explicit and repeated statement that oxidation in his apparatus comes to a definite end after 3 or 4 hours' shaking. The only exceptions the writer has 
noted were in those cases where the bark powder showed low oxidase activity to begin with, possibly due to injury of the "oxidase" during drying.

\section{TABLE III}

OXIDATION OF PYROCATECHIN, GUAIACOL, AND BENZIDINE BY HEALTHY AND

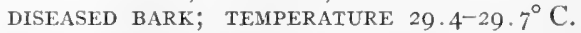

\begin{tabular}{|c|c|c|c|c|c|c|}
\hline \multirow[b]{2}{*}{ Time of REAding } & \multicolumn{3}{|c|}{ HeALthy } & \multicolumn{3}{|c|}{ Diseased } \\
\hline & Benzidine & Guaiacol & $\begin{array}{l}\text { Pyrocate- } \\
\text { chin }\end{array}$ & Benzidine & Guaiacól & $\begin{array}{l}\text { Pyrocate- } \\
\text { chin }\end{array}$ \\
\hline $\begin{array}{c}\text { June } 8, \text { I: } 30 \text { P.M.... } \\
\text { 4:30 after }\end{array}$ & 0.0 & 0.0 & 0.0 & 0.0 & 0.0 & 0.0 \\
\hline shaking 3 hours. & 0.08 & 0.33 & I. I3 & 0.65 & 0.75 & $3 \cdot 77$ \\
\hline June 9,8 : Io A.M... & 0.25 & 0.35 & I. 45 & 0.80 & I. .00 & $4 \cdot 35$ \\
\hline 2:20 P.MF... & 0.38 & 0.48 & 1.65 & 0.98 & I. .07 & $4 \cdot 55$ \\
\hline " IO, 9:I5 A.M... & 0.40 & 0.55 & I. 85 & I. 27 & I. 20 & 4.87 \\
\hline "II, 8:20 A.M... & 0.65 & 0.65 & 2,12 & I. 45 & I. 47 & 5.12 \\
\hline
\end{tabular}

That the rate and temperature of drying have an effect on the oxidase activity as well as on the hydrogen ion concentration is clearly shown in table IV.

\section{TABLE IV}

EFFECT OF RATE AND TEMPERATURE OF DRYING UPON OXIDASE ACTIVITY AND HYDROGEN ION CONCENTRATION OF HEALTHY AND DISEASED APPIE BARK

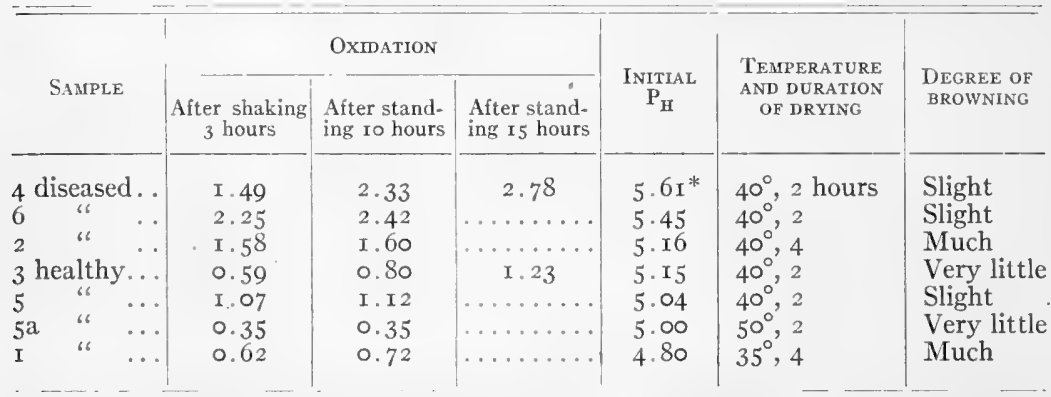

* This figure is the negative logarithmic exponent of ro where the whole expression $10=5 \cdot 61$ is a measure of the hydrogen ion concentration in the solution. The larger it is, therefore, the smaller the hydrogen ion concentration it expresses. In this particular case it can be written $2.454 \times 10^{-6}(6.00-$ $5.61=0.39$. Antilog $0.39=2.454$ ). In the amplified form this becomes 0.000002454 (normal).

Samples I, 2, 5, 5a, and 6 were all run in one experiment. Oxidation data for samples 3 and 4 are taken from table II and from another experiment not recorded in this paper. Samples 5 and $5 \mathrm{a}$ were parts of the same lot of ground bark but received 
different treatments as shown. The results show that oxidase activity is much reduced by drying at $35-40^{\circ}$ for 4 hours (sample I, healthy; sample 2 , diseased), or at $50^{\circ}$ for 2 hours (sample $5 \mathrm{a}$, healthy).

Hydrogen ION CONCENTRATION.-Hydrogen ion determinations on mixtures of bark and water and of bark, water, and pyrogallol, used in the same proportions as in the oxidase apparatus, showed that pyrogallol has no effect on the reaction. It was found possible to get constant initial readings on all mixtures-containing healthy bark and pyrogallol in 30-45 minutes; the same period sufficed for mixtures containing diseased bark and pyrogallol after they had been shaken in the oxidase apparatus, but not for similar mixtures freshly made up and not shaken. In these cases the potential increased slowly for an hour or two from about $P_{\mathrm{H}}=5.60$ to $P_{H}=5.40$, but never reached the figure given by healthy bark.

Culpepper, Foster, and CALDWELL (I6), working with normal and diseased Red Astrachan apples, state that when titrations were made on fruit pulp suspended in water "the diffusion of acids out of the tissues continues for many hours and at slower rates in diseased than in normal fruits," but in the light of the following results the writer is inclined to think this increase of acidity was due to oxidation going on in the solutions, and not to diffusion of acids out from the tissues.

TABLE $V$

CORRELATION BETWEEN OXIDASE ACTIVITY AND HYDROGEN ION CONCENTRATION OF MIXTURES CONTAINING PYROGALLOL, WATER, AND EITHER HEALTHY OR DISEASED BARK; TEMPERATURE $29-30.5^{\circ} \mathrm{C}$.

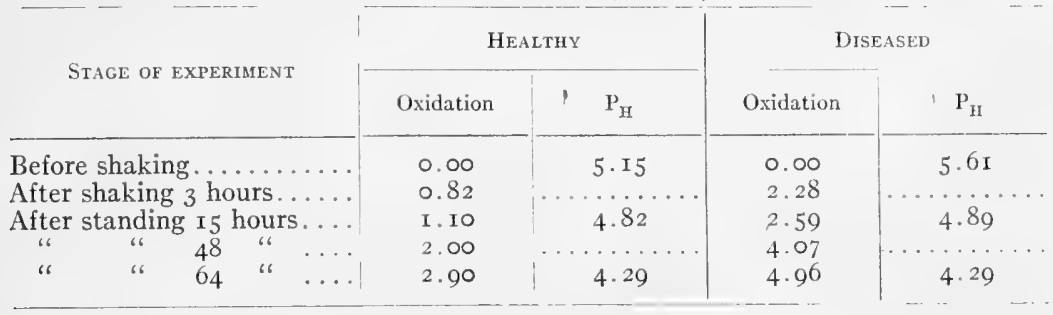

INCREASE IN HYDROGEN ION CONCENTRATION DURING OXIDATION.- Experiments designed to test more fully the theory that oxidation causes an increase in acidity are summarized in table $\mathrm{V}$. 
It is clear from table $\mathrm{V}$ that oxidation in these mixtures is accompanied by a marked increase in hydrogen ion concentration, and the conclusion certainly seems justified that there is a causal relation between the two. It is also seen that when oxidation comes to an end, both mixtures have the same reaction, $\mathrm{P}_{\mathrm{H}}=4.29$, a condition suggesting that at this point the hydrogen ion is the limiting factor.

BUNZELL (12) and REED (28) have studied the effect of hydrogen ion concentration on oxidation, but apparently neither of them has realized that it might increase during the oxidation process (30). They apparently assume that the hydrogen ion concentration established at the beginning of an experiment remains constant until the end, whereas the results given show that in these cases it increased as long as the oxidation continued.

In order to discover, if possible, what relation exists between oxidation and hydrogen ion concentration in the oxidase apparatus, further experiments were tried with mixtures of bark, dry pyrogallol, and, instead of water, $5 \mathrm{cc}$. of buffer solutions containing various amounts of $\mathrm{N} / \mathrm{I}$ o sodium acetate and either $\mathrm{N} /$ ro or $\mathrm{N} /$ roo acetic acid. The initial reactions of these mixtures (before shaking) and of the buffers alone are given in table VI and shown graphically in fig. 2 .

TABLE VI

REACTION, PH, OF BUFFER SOLUTIONS AND MIXTURES OF BUFFER SOLUTIONS, BARK, AND PYROGALLOL

\begin{tabular}{c|c|c|c|c|c|c|c|c|c}
\hline Solution & I & 2 & 3 & 4 & 5 & 6 & 7 & 8 & 9 \\
\hline $\begin{array}{l}\text { Buffer alone...... } \\
\text { Buffer and healthy } \\
\text { bark and pyro- }\end{array}$ & 6.02 & 5.73 & $5.4 \mathrm{I}$ & 5.17 & 4.80 & 4.53 & $4.2 \mathrm{I}$ & 3.90 & $3.6 \mathrm{I}$ \\
$\begin{array}{r}\text { gallol......... } \\
\text { Buffer and diseased } \\
\text { bark and pyro- } \\
\text { gallol........... }\end{array}$ & 5.59 & 5.52 & 5.36 & 5.15 & 4.85 & 4.58 & 4.24 & 3.98 & $3.6 \mathrm{I}$ \\
\hline
\end{tabular}

Graphs B and C in fig. 2 show that while diseased bark absorbs $\mathrm{H}^{+}$ions to about the same extent as the healthy, the latter absorbs more $\mathrm{OH}^{-}$ions; that is, its titration acidity is greater, which is exactly the condition found by titration with $\mathrm{N} / 20$ sodium hydroxide (30). The $P_{\mathrm{B}}$ values at points where $\mathrm{B}$ and $\mathrm{C}$ cross $\mathrm{A}$ 


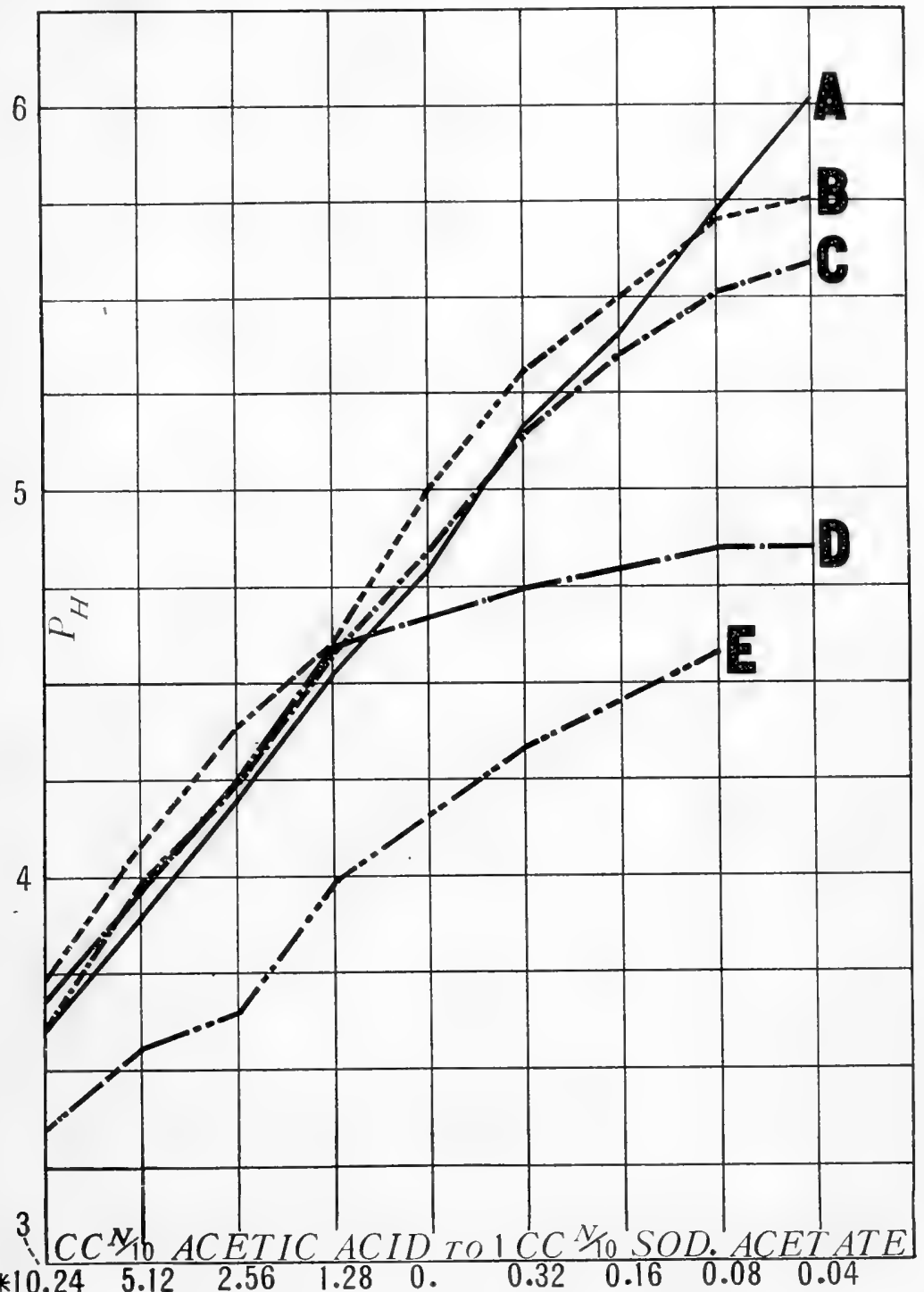

FIG. 2.- $\mathrm{PH}^{\mathrm{H}}$ of mixtures of bark, pyrogallol, and various buffer solutions before and after oxidation had ceased: $A, P_{\mathrm{H}}$ of buffer solutions; $B, \mathrm{P}_{\mathrm{zI}}$ of mixtures of buffer solutions, pyrogallol, and diseased bark before oxidation; $\mathrm{C}, \mathrm{P}_{\mathrm{H}}$ of mixtures of buffer solutions, pyrogallol, and healthy bark before oxidation; $\mathrm{D}, \mathrm{P}_{\mathrm{H}}$ of mixtures of buffer solutions, pyrogallol, and diseased bark after oxidation; $\mathrm{E}, \mathrm{P}_{\mathrm{H}}$ of mixtures of buffer solutions, pyrogallol, and healthy bark after oxidation. *Only acetic acid used here. 
(healthy bark about 5. I0, diseased about 5.65) agree well with those determined without the buffer $\left(P_{\mathrm{H}}\right.$ healthy $=5$. I 5 , diseased $=$ $5.6 \mathrm{I})$; the latter are taken, therefore, to represent practically the actual acidity in each case. This is based on the assumption that if the acidity of a buffer solution is the same as that of a mixture of bark, pyrogallol, and water, no change in acidity will take place when the buffer is used instead of water.

EFFECT OF BUFFER SOLUTIONS.-The oxidations brought about by mixtures of bark, pyrogallol, and the various buffer solutions are given in table VII, together with the initial $P_{\text {п }}$ of these mixtures and their $\mathrm{P}_{\mathrm{II}}$ after oxidation had practically ceased.

TABLE VII

OXIDATION BY MIXTURES OF BARK AND PYROGALLOL WITH VARIOUS BUFFER SOLUTIONS; TEMPERATURE $29-30^{\circ} \mathrm{C}$.

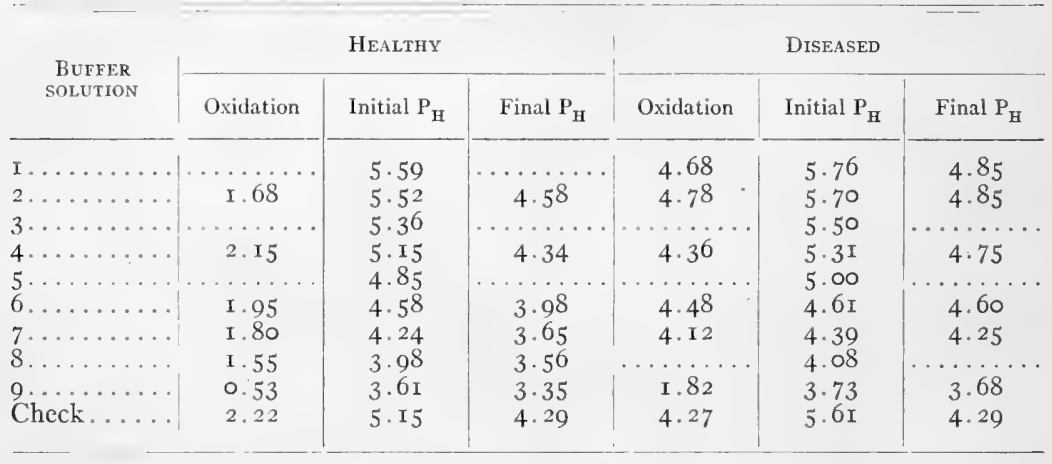

The principal fact shown by the results in table VII is that the $\mathrm{P}_{\mathrm{B}}$ (4.29) reached by mixtures of pyrogallol, water, and either healthy or diseased bark when oxidation comes to an end is not sufficient to inhibit oxidation when the mixture has that $\mathrm{P}_{\mathrm{B}}$ value to begin with; in fact, a greater degree of acidity does not inhibit entirely, since a healthy bark mixture with an initial $\mathrm{P}_{\text {в }}$ of $3.6 \mathrm{I}$ gave an oxidation (a mercury rise) of $0.53 \mathrm{~cm}$., and a diseased bark mixture with an initial $\mathrm{P}_{\mathrm{B}}$ of 3.78 gave an oxidation of I. $82 \mathrm{~cm}$. The check, bark, pyrogallol, and water gave, in the former case, $2.22 \mathrm{~cm}$. mercury rise, and in the latter $4.27 \mathrm{~cm}$.

It might seem from this that the acidity brought about in mixtures of bark, pyrogallol, and water is not the factor which 
brings oxidation to an end. It seems more reasonable to suppose, however, that the time factor is of importance here; that is, that an acidity of $P_{H}=4.29$ is more effective when reached gradually than when established as a starting point. Looking at the situation from another angle, we may say that inhibition is total if the initial hydrogen ion concentration is high enough, but will be only partial if the concentration is lower; but since partial inhibition means some oxidation, which in itself increases acidity, the process in time necessarily comes to an end. The hydrogen ion concentration at that point will depend on what it was in the beginning, but will never be equal to that which causes total inhibition.

That this theory fits the facts is shown by table VII. Oxidation took place in all the mixtures, the amount depending on the initial hydrogen ion concentration, except where diseased bark was used with buffer no. 4. Acidity increased in all the mixtures but one, diseased bark with buffer no. 6 (see tables VI and VII). The increase in acidity is shown graphically in fig. 2. It is unexpectedly small for diseased bark except where the 3 most alkaline buffers were used, a condition which suggests the need of further experiments.

In figs. 3 and 4 are shown graphically the oxidation data given in table VII, representing the final amounts of oxidation for each set of tests (healthy and diseased bark with the different buffer solutions). In addition there are shown graphs for several earlier stages in each experiment. These graphs show that below $\mathrm{I} \times \mathrm{IO}^{-4}\left(\mathrm{P}_{\mathrm{H}}=4\right)$ for healthy bark, and $2.5 \times 10^{-5}\left(\mathrm{P}_{\mathrm{H}}=4.39\right)$ for diseased bark, oxidation drops rapidly as acidity increases. Above these points the changes are not so marked. The hydrogen ion concentration for total inhibition, estimated by extrapolation to the base line, lies between 3.55 and $3.80 \times 10^{-4}$ for healthy and between 3.55 and $4.27 \times \mathrm{IO}^{-4}$ for diseased bark. All these figures closely approximate those found by BUNzELL (I2) for potato oxidase, 2.I$2.8 \times \mathrm{IO}^{-4}$, and by REED (28) for apple oxidase, 5.0-7.0 $\times \mathrm{rO}^{-4}$.

The results given in table VII show that hydrogen ion concentration is not the only factor effective in controlling oxidation in the apparatus, and consequently that the lower hydrogen ion concentration of diseased bark cannot account entirely for its 
greater oxidizing power. For example, when both kinds of bark were brought to approximately the same hydrogen ion concentration by buffer no. 6 , the final amount of oxidation (mercury rise) for healthy bark was I.95 and for diseased 4.48 , the final $\mathrm{P}_{\text {в } 3.98}$ and 4.60 respectively. The total oxidase activity of the diseased plant is the joint oxidase activity of the host and parasite, while

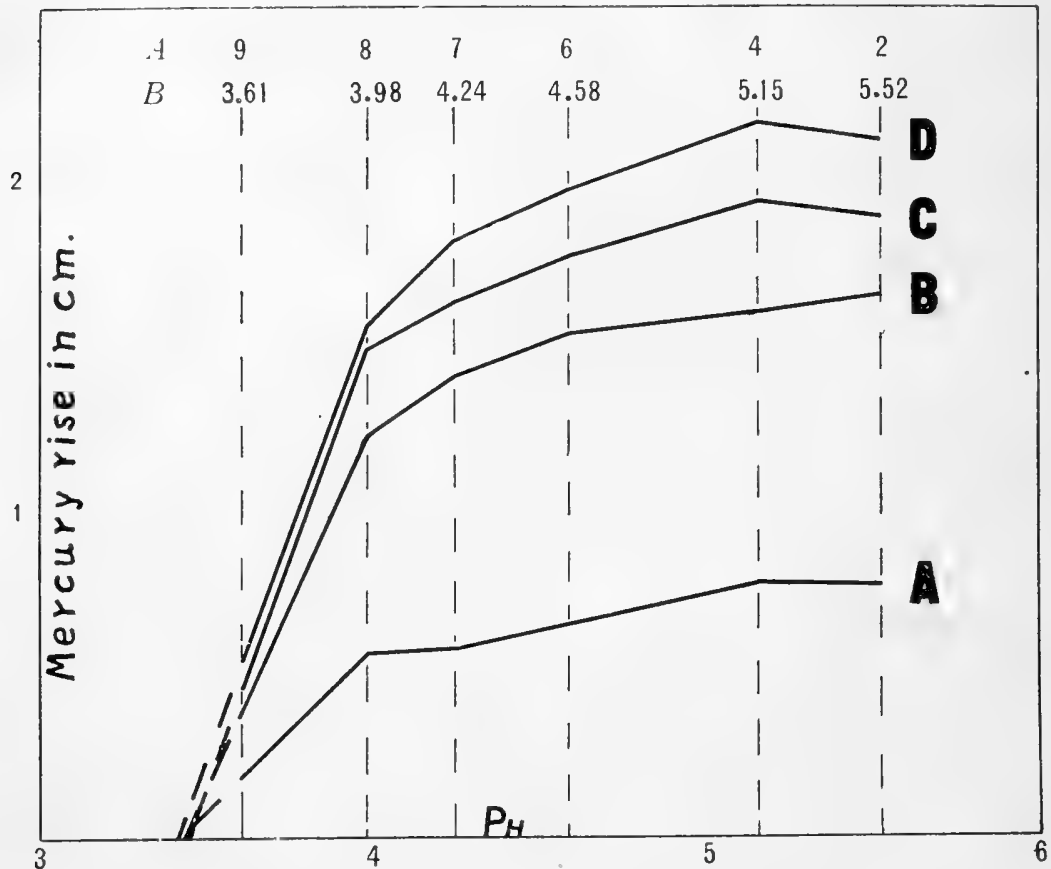

FIG. 3.-Oxidation of mixtures of healthy bark, pyrogallol, and various-buffer solutions: A, after 3 hours; B, after 22 hours (I9 hours without shaking); C, after 29 hours; D, after 48 hours; $A$, bark, pyrogallol, and buffer solutions as indicated by numbers; $B$, initial $\mathrm{P}_{\mathrm{H}}$; points of plotting marked by vertical broken lines.

the oxidase activity of the healthy plant is that of the host alone. This may account in part for the difference both in rate of activity and in the $\mathrm{P}_{\mathrm{II}}$ concentration at the time the action ceases.

NAture of Equilibrium REAched.-Bunzell (13), in experiments with potato peel powder, has obtained what he considers evidence that "the activity of the plant powder is not paralyzed by the products formed in the course of the reaction." He found 


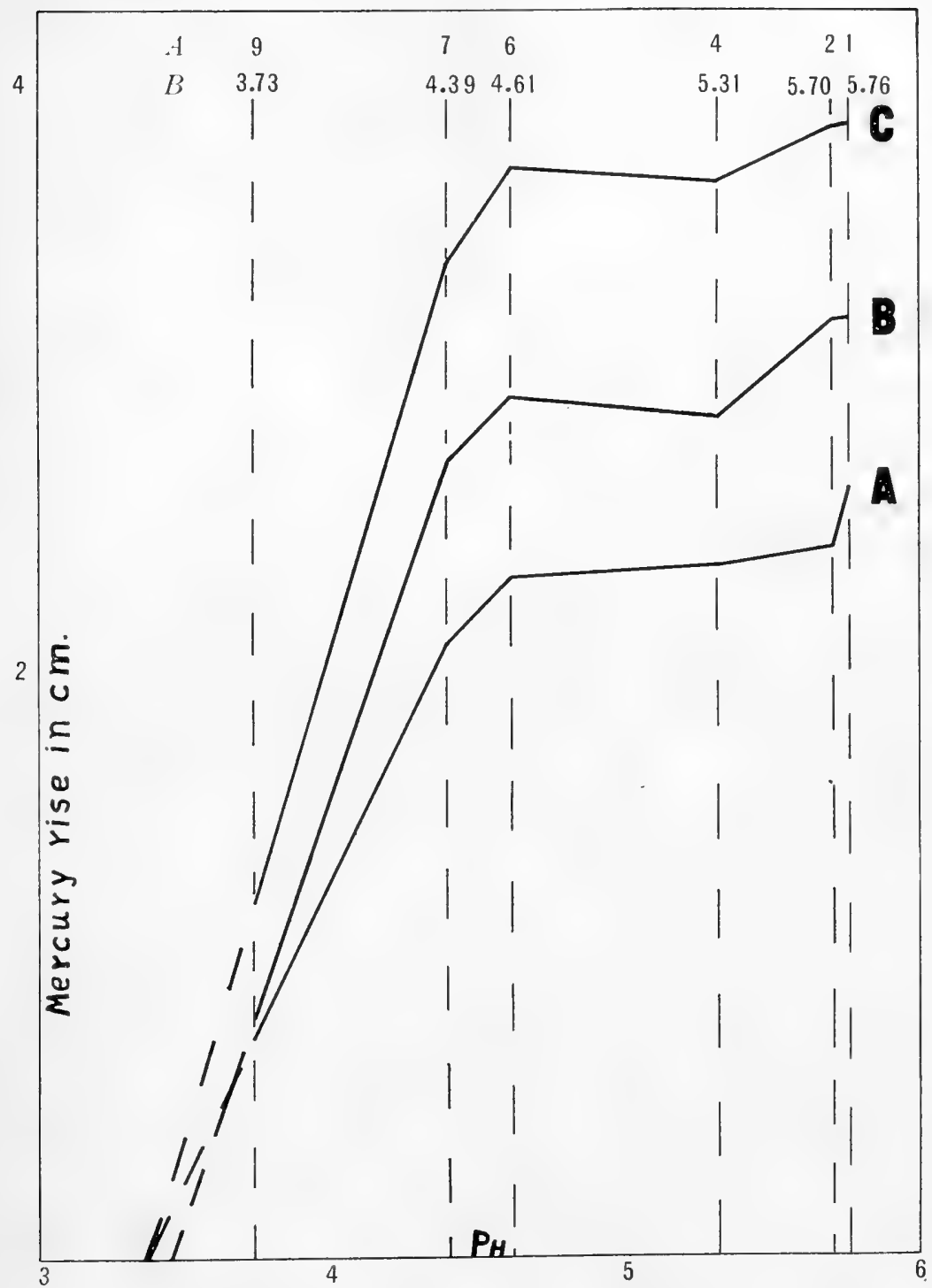

FIG. 4.-Oxidation by mixtures of diseased bark, pyrogallol, and various buffer solutions: A, after 23 hours (shaken 2 hours of this time); B, after 45.5 hours; C, after 69.5 hours; $A$ and $B$ as in fig. 3 . 
that by adding a second portion of the powder to the apparatus in which oxidation by the first portion had ceased he could cause a further increase in oxidation, the amount of increase varying with the oxidase reagent used. The writer has found a similar increase in oxidation when more oxidase reagent is added, after oxidation ceases. The results of an experiment of this kind are summarized in table VIII. Results are given beginning with the TABLE VIII

SUMMARY OF RESULTS FROM AN EXPERIMENT TO TEST EFFECT OF ADDING FRESH SUPPLY OF OXIDASE REAGENT.

\begin{tabular}{|c|c|c|c|c|c|}
\hline \multirow{2}{*}{ Experiment } & \multirow{2}{*}{$\begin{array}{l}\text { Stage of experi- } \\
\text { ment }\end{array}$} & \multicolumn{4}{|c|}{$\begin{array}{l}\text { Increase in oxidation (cm. of } \\
\text { mercury rise) }\end{array}$} \\
\hline & & 8 & 9 & 10 & II \\
\hline $\begin{array}{l}\text { Effect of adding } 7 \text { and } 4 \text { drops I per cent } \\
\text { benzidine to apparatus Io and II on } \\
\text { ninth day, } 8 \text { and } 9 \text { as checks........ }\end{array}$ & gth to IIth & 0.00 & 0.02 & 0.49 & O.I9 \\
\hline $\begin{array}{l}\text { Effect of adding ro drops I per cent ben- } \\
\text { zidine to apparatus ro and I I on }\end{array}$ & $T_{1}$ th & & & & \\
\hline $\begin{array}{l}\text { Total effect of } \mathrm{I} \text { per cent benzidine, } 8 \text { as } \\
\text { check. }\end{array}$ & $\begin{array}{l}\text { IIth to I4th } \\
\text { oth to } 26 \text { th }\end{array}$ & 0.47 & 0. & I. I6 & 0.71 \\
\hline $\begin{array}{l}\text { Effect of adding } 0.06 \text { gm. of pyrogallol } \\
\text { to } 8 \text { on twenty-sixth day........... }\end{array}$ & 26 th to $4 \mathrm{Ist}$ & I. 53 & & 1.95 & 1.34 \\
\hline 8 as check $\ldots$ & gth to 26 th & 0.47 & & & \\
\hline on fourteenth day, 8 as check . $\therefore$.... & I4th to $2 \mathrm{Ist}$ & ०.19 & 0.74 & & \\
\hline $\begin{array}{l}\text { alcohol to } 9 \text { on twenty-first day, } 8 \text { as } \\
\text { check. . . . . . . . . . . . . . }\end{array}$ & 2 Ist to 26 th & O. II & 0.68 & & \\
\hline
\end{tabular}

ninth day of the experiment. Up to that time oxidation in all 4 of the tubes was practically the same, the average being 3 .I 2 (cm. of mercury rise). Alcohol was used at the beginning of the experiment to discover whether it has an inhibiting effect on oxidation, and later, when solid benzidine was added, to bring the benzidine into solution more rapidly. The results show that, in the small quantities used, the alcohol had no inhibiting effect (table VIII, ninth day, apparatus Io and II), and probably did bring the benzidine into solution (twenty-first-forty-first day, apparatus 9).

The most important fact shown by these results is that after oxidation had practically ended, the addition of more oxidase 
reagent was followed by a marked increase in oxidation. For example, in table VIII it is seen that from the ninth to the twentysixth day oxidation in apparatus 8 , containing pyrogallol and bark extract, showed an increase of only $0.47 \mathrm{~cm}$., while tubes Io and II, also containing pyrogallol and bark extract to which benzidine solution was added later, showed an increase of r.95 and I.34 cm. respectively. Equally marked excess over the check was obtained when solid pyrogallol or solid benzidine was added. One might infer that the oxygen admitted, when the tubes were opened to introduce reagents, increased oxidation, but this effect could hardly account for the difference observed. BunzeLL states that exhaustion of oxygen is not the limiting factor, and experiments by the writer have shown that, when a fresh oxygen supply is allowed to enter the apparatus, the subsequent increase in oxidation is small.

The fact that after oxidation ends it can be started afresh by the addition of fresh plant material or of fresh oxidase reagent suggests that the equilibrium reached is a false one, like the third case described by HöBER (23, p. 67I), in which a reaction product of the catalytic reaction brings about equilibrium by an inactivation of the catalyzer. A test for this condition according to HöBER is that reaction begins again when more catalyzer is added, as in the case of the hydrolysis of amygdalin by emulsin. The similarity between the two reactions, however, does not prove that the oxidation catalyst is an enzyme, for it may be non-enzymic in nature and still be inactivated by the products of the catalytic reaction.

An idea of the nature of the oxidase reaction was obtained by testing some of the data by the formula for unimolecular reaction, $k=\frac{I}{t} \log \cdot \frac{a}{a-x}$. In these calculations the total, amount of oxidation (mercury rise) at the end of the shaking period was assumed for the value of $a$, and the amount of oxidation at the end of each I5-minute interval for the value of $x$. The figures which should be used, of course, are the total amount of pyrogallol at the beginning of the experiment and the amount oxidized at the end of each I5-minute interval, but such figures would be difficult to obtain. The writer sees no reason why the values used for $a$ and $x$ do not truly represent the course of the reduction. 
In most cases the values of $k$ given in these tables are fairly constant and may be considered a strong indication that the oxidase reaction is unimolecular. In table XI, column 3 , table XII,

TABLE IX

HEALTHY BARK AND PYROGALLOL

\begin{tabular}{|c|c|c|c|}
\hline$t$ (min.) & $\begin{array}{c}x \text { (mercury rise } \\
\text { in } \mathrm{cm} .)\end{array}$ & $a-x$ & $k=\frac{\mathrm{I}}{t} \log \cdot \frac{a}{a-x}$ \\
\hline$I_{5} \ldots \ldots \ldots$ & 0.14 & 0.72 & $(0.005 \times 4$ \\
\hline $30 \ldots . .$. & 0.19 & 0.67 & 0.00361 \\
\hline $45 \ldots \ldots \ldots$ & 0.24 & 0.62 & 0.00315 \\
\hline $60 \ldots . . .$. & 0.34 & $0.5^{2}$ & 0.00365 \\
\hline $75 \ldots \ldots$ & 0.44 & 0.42 & $* 0.00415$ \\
\hline $90 \ldots$ & 0.49 & 0.37 & 0.00407 \\
\hline $105 \ldots \ldots \ldots$ & 0.54 & $0.3^{2}$ & 0.00409 \\
\hline$I 20 \ldots \ldots \ldots$ & 0.63 & 0.23 & 0.00477 \\
\hline $\mathrm{I}_{35} \ldots \ldots \ldots$ & 0.68 & 0.18 & 0.00503 \\
\hline$I_{5} 0 \ldots \ldots \ldots$ & 0.74 & O.I 2 & 0.00570 \\
\hline 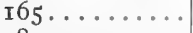 & 0.79 & 0.07 & 0.00660 \\
\hline I80. . . . . . . & 0.86 & $\ldots \ldots \ldots$ & $\ldots \ldots \ldots$ \\
\hline Mean.... & & & 0.00433 \\
\hline
\end{tabular}

* Brackets in this and following tables indicate those values of $k$ which were considered in calculating the mean.

TABLE X

Diseased BARK AND PYROGallol

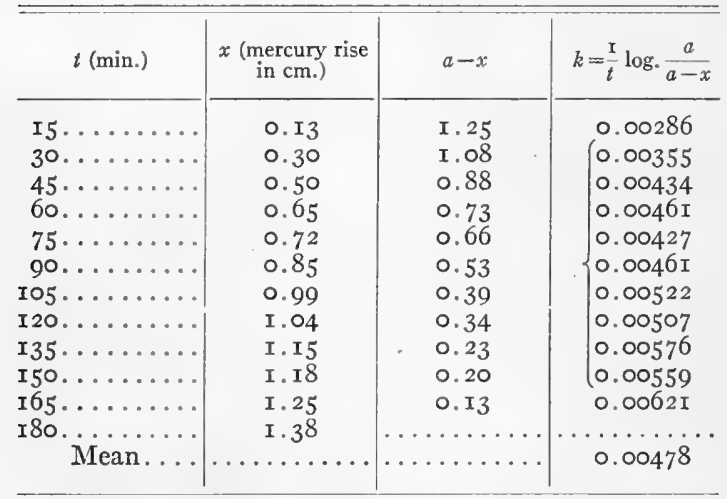

column I, and table XIV, column I, the values for $k$ show a gradual increase throughout the experiment, and can scarcely be taken to indicate a unimolecular reaction. Table XII, column I, however, is checked by tables IX and XII, column 3 , the mean value 
of $k$ being nearly the same in all 3 cases, although it is doubtful whether a mean for table XII, column $\mathrm{I}$, is really significant.

\section{TABLE XI}

VALUES OF $k$ CALCULATED FROM DATA OBTAINED IN EXPERIMENTS WITH APPLE BARK, $\mathrm{K}_{2} \mathrm{CO}_{3}$, AND PYROGALLOI

\begin{tabular}{|c|c|c|c|c|}
\hline \multirow[b]{2}{*}{$t(\min )$} & \multicolumn{4}{|c|}{$k$} \\
\hline & $\begin{array}{l}\mathrm{K}_{3} \mathrm{CO}_{3} \text { and } \\
\text { pyrogallol }\end{array}$ & $\begin{array}{c}\mathrm{K}_{2} \mathrm{CO}_{3} \text { and } \\
\text { pyrogallol }\end{array}$ & $\begin{array}{c}\text { Healthy bark, } \\
\mathrm{K}_{2} \mathrm{CO}_{3} \text {, and } \\
\text { pyrogallol }\end{array}$ & $\begin{array}{l}\text { Diseased bark, } \\
\mathrm{KC}_{3} \mathrm{O}_{3} \text {, and } \\
\text { pyrogallol }\end{array}$ \\
\hline I $5 \ldots \ldots$ & 0.00747 & $0.0055^{2}$ & 0.00114 & 0.00525 \\
\hline $30 \ldots \ldots$ & 0.00776 & 0.00803 & 0.00380 & $\{0.00600$ \\
\hline $45 \ldots \ldots$ & 0.00774 & 0.00773 & 0.00431 & 0.006 I 5 \\
\hline 60. & 0.00785 & 0.00786 & 0.00368 & 0.00604 \\
\hline $75 \ldots \ldots$ & 0.00808 & 0.00819 & 0.00472 & 0.00606 \\
\hline 90. & 0.00767 & 0.00750 & 0.00492 & 0.00628 \\
\hline 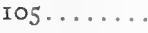 & 0.00765 & 0.00709 & 0.00514 & 0.00642 \\
\hline I 20. & 0.00786 & 0.00890 & 0.00470 & 0.00657 \\
\hline $\mathrm{I} 35 \ldots \ldots \ldots$ & 0.008 I I & $0.0094 \mathrm{I}$ & 0.00633 & 0.00700 \\
\hline I 50. & 0.00768 & 0.00947 & 0.00663 & 0.00678 \\
\hline $165 \ldots . .$. & 0.00805 & 0.00936 & 0.00692 & 0.00862 \\
\hline Mean. & $0.0078 \mathrm{I}$ & 0.00834 & $\cdots, 00482$ & 0.00635 \\
\hline
\end{tabular}

TABLE XII

VALUES OF $k$ CALCULATEd FROM DATA OBTATNED IN EXPERIMENTS WITH APPLE BARK, PYROGALLOL, AND PYROCATECHIN

\begin{tabular}{|c|c|c|c|c|}
\hline \multirow[b]{2}{*}{$t$ (min.) } & \multicolumn{4}{|c|}{$k$} \\
\hline & $\begin{array}{l}\text { Healthy bark } \\
\text { and pyrogallol }\end{array}$ & $\begin{array}{l}\text { Diseased bark } \\
\text { and pyrogallol }\end{array}$ & $\begin{array}{l}\text { Healthy bark } \\
\text { and pyrocat- } \\
\text { echin }\end{array}$ & $\begin{array}{l}\text { Diseased bark } \\
\text { and pyrocat- } \\
\text { echin }\end{array}$ \\
\hline I5 . . & 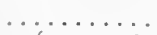 & $\left(0.0045^{8}\right.$ & $(0.00502$ & 0.00483 \\
\hline $30 \ldots \ldots$ & $(0.00246$ & 0.00528 & 0.00429 & 0.00494 \\
\hline $45 \ldots .$. & 0.00277 & 0.00515 & 0.00357 & 0.00510 \\
\hline $60 \ldots . .$. & 0.00322 & 0.00515 & 0.00346 & 0.00488 \\
\hline $75 \ldots \ldots$ & 0.00383 & 0.00510 & 0.00416 & 0.00526 \\
\hline $90 \ldots .$. & 0.00493 & 0.00530 & 0.00433 & 0.00536 \\
\hline $105 \ldots . .$. & 0.00460 & 0.00507 & 0.00426 & 0.00553 \\
\hline I $20 \ldots . .$. & 0.00501 & 0.00575 & 0.00434 & 0.00584 \\
\hline I $35 \ldots \ldots$ & 0.00584 & 0.00604 & 0.00483 & $0.006 \mathrm{I} 3$ \\
\hline I $50 . .$. & 0.00886 & 0.00744 & 0.00548 & 0.00690 \\
\hline I65 ....... & $\ldots \ldots \ldots$ & $\ldots \ldots \ldots$ & 0.00590 & 0.00866 \\
\hline ISo. Mean & ….... & $\cdots \cdots \cdots \cdots$ & $\cdots \ldots \ldots$ & $\cdots \ldots \ldots$ \\
\hline Mean.. & 0.00430 & 0.00527 & $0.0045 \mathrm{I}$ & $0.0052 \mathrm{I}$ \\
\hline
\end{tabular}

Confirmation of the results with apple bark is found in table XIII and table XIV, column 2, based on data obtained by 
Bunzell (9, I3) with tulip tree leaves and with potatoes, although the mean value of $k$ in all 3 cases is much larger than that found for bark. Attention has already been called to the fact that the data in table XIV, column I (also from BunZELL'S work), fail to fit the equation for a unimolecular reaction. The fact of a marked rise

TABLE XIII

VALUES OF $k$ CALCULATED FROM DATA PUBLISHED BY Bunzell (9) For POTATO JUICE

AND PYROGALLOI

\begin{tabular}{|c|c|c|c|}
\hline$l(\min )$ & $k^{*}$ & $t(\min )$ & $k \dagger$ \\
\hline 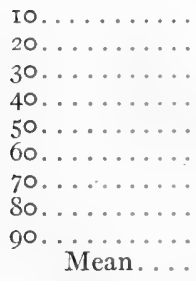 & $\left\{\begin{array}{l}0.0315 \\
0.0266 \\
0.0240 \\
0.0216 \\
0.0244 \\
0.0277 \\
0.0255 \\
0.0283 \\
\ldots .0262 \\
0.026\end{array}\right.$ & $\begin{array}{r}10 \ldots \ldots \\
30 \ldots \ldots \\
45 \ldots \ldots \\
60 \ldots \ldots \\
75 \ldots \ldots \\
90 \ldots \ldots \\
\text { I05 } \ldots \ldots \ldots \\
\text { Mean... }\end{array}$ & $\begin{array}{r}\left\{\begin{array}{l}0.0246 \\
0.0277 \\
0.0199 \\
0.0168 \\
0.0174 \\
0.0233\end{array}\right. \\
\ldots \ldots .0208 \\
0.020\end{array}$ \\
\hline
\end{tabular}

* 23, p. 29, table VII, columns I and 4 .

$\dagger 23$, p. 26 , table II, columns 5 and 7 .

TABLE XIV

Values of $k$ CALCUlated from data PUblished by Bunzell (I3)

\begin{tabular}{|c|c|c|c|c|c|}
\hline \multirow{2}{*}{$t$ (min.) } & \multicolumn{2}{|c|}{$k$} & \multirow{2}{*}{$t$ (min.) } & \multicolumn{2}{|c|}{$k$} \\
\hline & $\begin{array}{l}\text { Spinach leaves } \\
\text { and para-cresol }\end{array}$ & $\begin{array}{c}\text { Tulip tree leaves } \\
\text { and phlorhizin }\end{array}$ & & $\begin{array}{l}\text { Spinach leaves } \\
\text { and para-cresol }\end{array}$ & $\begin{array}{l}\text { Tulip tree leaves } \\
\text { and phlorhizin }\end{array}$ \\
\hline I $5 \ldots$ & 0.00374 & 0.0124 & 90. & $0.010 I 8$ & $\ldots$ \\
\hline 30. & 0.00654 & 0.0119 & 105. & $\ldots \ldots \ldots \ldots$ & $\ldots$ \\
\hline 45. & 0.00640 & 0.0133 & I 20. & $\ldots \ldots \ldots \ldots$ & $\ldots \ldots \ldots \ldots$ \\
\hline 60. & 0.00940 & 0.0137 & I 35. & $\ldots \ldots \ldots \ldots$ & $\ldots \ldots \ldots \ldots$ \\
\hline $75 \ldots$ & 0.01092 & $\ldots \ldots \ldots \ldots$ & Mean. . & $\ldots \ldots \ldots \ldots$ & 0.0137 \\
\hline
\end{tabular}

in the value of $k$ toward the end of the experiments with bark may mean that at that point the "oxidase" oxidizes not constant fractions but constant weights of pyrogallol in a given time (PHILIP 27, p. 295). The data at hand, however, are insufficient for a verification of this hypothesis. 
A unimolecular reaction is one in which the concentration of only one substance is changed. If oxidation of pyrogallol by plant material in the oxidase apparatus be such a reaction, the substance whose concentration is changed is pyrogallol. The "oxidase" then appears as the catalyst, its concentration remaining unchanged during the course of the reaction. Even at that it is not necessarily proved to be an enzyme, since the linear relationship between time and amount of change is also shown in the oxidation of pyrogallol by potassium carbonate.

EFFect of AdDing PRotective colloids.-Bayliss (6) and PERRIN (26) have suggested that the oxidizing enzyme is an active form of the colloidal hydroxide of manganese, iron, or copper, kept in this active state by an emulsion colloid such as gum or albumin, acting as a protective colloid. Tables XV and XVI show the effects of additions of gelatine and gum arabic. Table XV shows that 0.2 per cent gelatine increases considerably the oxidation by healthy bark and only slightly that by diseased bark. Three other experiments with pyrogallol and 2 with pyrocatechin with 0.2 per cent gelatine added showed similar results. The use of 0.8 per cent gelatine with pyrogallol also showed a similar effect. Both 0.2 and 0.8 per cent gum arabic had little or no effect on healthy bark and a slight accelerating effect on diseased bark.

TABLE XV

EFFECT OF 0.2 PER CENT GELATINe ON OXIDATION OF PYROGALLOL By HEALThy AND DISEASED BARK; TEMPERATURE $22-24^{\circ} \mathrm{C}$.

\begin{tabular}{|c|c|c|c|c|c|}
\hline & \multirow{2}{*}{ TIME OF READING } & \multicolumn{2}{|c|}{ Healthy } & \multicolumn{2}{|c|}{ Diseased } \\
\hline & & Without gelatine & With gelatine & Without gelatine & With gelatine \\
\hline $\begin{array}{l}66 \\
66 \\
66\end{array}$ & 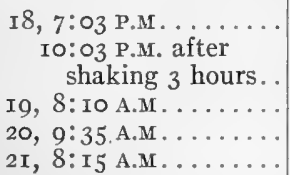 & $\begin{array}{l}0.0 \\
0.77 \\
0.94 \\
1.37 \\
1.65\end{array}$ & $\begin{array}{l}0.0 \\
0.81 \\
1.32 \\
2.26 \\
2.74\end{array}$ & $\begin{array}{l}0.0 \\
2.22 \\
2.40 \\
2.88 \\
3.17\end{array}$ & $\begin{array}{l}0.0 \\
2.24 \\
2.54 \\
3.00 \\
3.27\end{array}$ \\
\hline
\end{tabular}

Since gelatine is amphoteric, one might infer that it or its splitting products act as buffers, thus reducing the rate of increase of the hydrogen ion concentration with progress of the oxidation 
(fig. 5). Table XVII, however, shows that gelatine has little effect on the hydrogen ion concentration of oxidizing mixtures of either healthy or diseased bark.

Precipitated oxidases.--Experiments were run using precipitated "oxidases," prepared as follows: 2 gm. of bark were allowed to extract with Io cc. of water and 5 drops of toluol for I hour; the extract was then squeezed through moist cheesecloth on to coarse filter paper, the beaker washed with five I cc. portions of water and the filter paper finally with two more; $50 \mathrm{cc}$. of 95 per

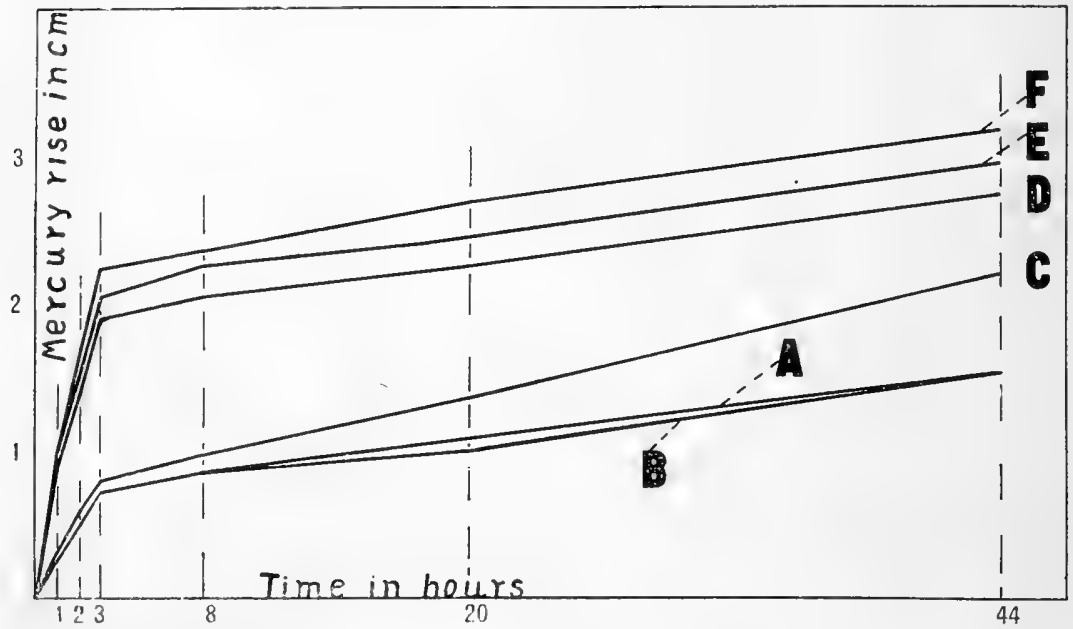

FIG. 5.-Effect of 0.8 per cent gum arabic and 0.8 per cent gelatine on oxidation of pyrogallol by healthy and diseased bark: A, healthy bark; B, healthy bark and gum arabic; C, healthy bark and gelatine; D, diseased bark; E, diseased bark and gum arabic; $\mathrm{F}$, diseased bark and gelatine.

cent alcohol were then added to the filtrate (concentration of alcohol about 70 per cent), the whole allowed to stand for ro minutes and the flocculent precipitate collected on a hard filter by gentle suction with a filter pump; I $50 \mathrm{cc}$. more alcohol were then added to the filtrate (concentration of alcohol now about 90 per cent) and the whole allowed to stand for I hour, since precipitation was slow, before collecting this second fraction on the filter with the first. The precipitate from diseased bark was much browner than that from healthy bark. Whether this bears any relation to its greater oxidase activity is not known. 
For tests in the oxidase apparatus the combined precipitates were dissolved in $20 \mathrm{cc}$. of water, and $2 \mathrm{cc}$. of this solution containing the precipitate obtained from o.I gm. of bark was put in each apparatus together with the usual amounts of pyrogallol and water.

\section{TABLE XVI}

EFfect OF 0.2 PER CENT GUM ARABIC, O. 8 PER CENT GUN ARABIC, AND 0.8 PER CENT GELATINE ON OXIDATION OF PYROGALLOL BY HEALTHY AND DISEASED BARK; TEMPERATURE $2 \mathrm{I}-23^{\circ} \mathrm{C}$.

\begin{tabular}{|c|c|c|c|c|c|c|c|c|}
\hline \multirow{3}{*}{ Time of READING } & \multicolumn{4}{|c|}{ Healthy } & \multicolumn{4}{|c|}{ DISEASED } \\
\hline & \multirow{2}{*}{$\begin{array}{c}\text { No } \\
\text { addition }\end{array}$} & \multirow{2}{*}{$\begin{array}{c}\text { Gelatine } \\
0.8 \text { per } \\
\text { cent }\end{array}$} & \multicolumn{2}{|c|}{ Gum arabic } & \multirow{2}{*}{$\begin{array}{c}\text { No } \\
\text { addition }\end{array}$} & \multirow{2}{*}{$\begin{array}{c}\text { Gelatine } \\
0.8 \text { per } \\
\text { cent }\end{array}$} & \multicolumn{2}{|c|}{ Gum arabic } \\
\hline & & & $\begin{array}{l}0.2 \text { per } \\
\text { cent }\end{array}$ & $\begin{array}{l}0.8 \text { per } \\
\text { cent }\end{array}$ & & & $\begin{array}{l}0.2 \text { per } \\
\text { cent }\end{array}$ & $\begin{array}{l}0.8 \text { per } \\
\text { cent }\end{array}$ \\
\hline $\begin{array}{l}\text { At beginning.... } \\
\text { After shaking } 3\end{array}$ & 0.00 & 0.00 & 0.00 & 0.00 & 0.00 & 0.00 & 0.00 & 0.00 \\
\hline hours........ & 0.70 & 0.78 & 0.65 & $0.7 \mathrm{I}$ & I. 88 & 2.23 & 2. I9 & 2.05 \\
\hline After 18.5 hours & I.03 & I. 34 & 1.00 & I.OI & $2 \cdot 36$ & 2.69 & $2.7 \mathrm{I}$ & 2.46 \\
\hline $\begin{array}{l}\text { After } 42 \text { hours. } \\
\text { Average of }\end{array}$ & I. 50 & 2.20 & $\ldots \ldots$ & I. 54 & 2.73 & 3.18 & $\ldots \ldots$ & 2.95 \\
\hline$-\quad-1$ & 2 & $\ldots \ldots$ & & & 2 & & & $\ldots$ \\
\hline
\end{tabular}

In table XVIII are given results showing the oxidizing power of these solutions, with and without gelatine (fig. 6).

The relation observed with bark powder still holds here, that diseased material is more active than healthy. On the other hand, gelatine increases oxidation by the precipitate from extract of

TABLE XVII

REACTION OF MEXTURES OF BARK AND PYROGALLOL WITH GELATINE (0.2 PER CENT) AND WITHOUT AT VARIOUS STAGES OF OXWATION PROCESS

\begin{tabular}{|c|c|c|c|c|c|}
\hline & \multirow{2}{*}{ TIME OF REAdiNg } & \multicolumn{2}{|c|}{ Healthy } & \multicolumn{2}{|c|}{ Diseased } \\
\hline & & Without gelatine & With gelatine & Without gelatine & With gelatine \\
\hline$P_{\text {H }}$ & $\left\{\begin{array}{l}\text { Initial } \ldots \ldots . . \\
\text { After is hours... } \\
\text { After } 64 \text { hours. }\end{array}\right.$ & $\begin{array}{l}5.15 \\
4.82 \\
4.29\end{array}$ & $\begin{array}{l}5.15 \\
4.84 \\
4.35\end{array}$ & $\begin{array}{l}5.6 \mathrm{I} \\
4.89 \\
4.29\end{array}$ & $\begin{array}{l}5 \cdot 60 \\
4.86 \\
4 \cdot 5^{2}\end{array}$ \\
\hline
\end{tabular}

diseased bark, but is without marked effect on that from healthy bark, the reverse of the condition found when bark powder was used.

There were indications in the preliminary work that the alcoholic precipitate from bark extract was easily separated into 2 
fractions, hence it seemed worth while to collect these separately. This was done for both healthy and diseased tissue and gave

TABLE XVIII

OxIDATION OF PYROGALLOL BY AQUEOUS SOLUTIONS OF PRECIPITATED OXIDASE FROM HEALTHY AND DISEASED BARK, WITH AND WITHOUT GELATINE; TEMPERATURE $29 \cdot 3-30.3^{\circ} \mathrm{C}$.

\begin{tabular}{|c|c|c|c|c|c|}
\hline & \multirow{2}{*}{ TIME OF READING } & \multicolumn{2}{|c|}{ Healthy } & \multicolumn{2}{|c|}{ Diseased } \\
\hline & & Without gelatine & With gelatine & Without gelatine & With gelatine \\
\hline $\begin{array}{c}\text { June } \\
\text { "6 }\end{array}$ & $\begin{array}{l}28,4: 35 \text { P.M. ....... } \\
29,8: 45 \text { A.M. . . . . . } \\
\text { I I : } 45 \text { A.M. after } \\
\text { shaking } 3 \text { hours... } \\
\text { 30, } 8: 30 \text { A.M. ........ }\end{array}$ & $\begin{array}{l}0.0 \\
0.31 \\
0.35 \\
0.42\end{array}$ & $\begin{array}{l}0.0 \\
0.33 \\
0.46 \\
0.46\end{array}$ & $\begin{array}{l}0.0 \\
0.68 \\
\text { I. } 01 \\
\text { I. } 08\end{array}$ & $\begin{array}{l}0.0 \\
0.72 \\
\text { I. } 24 \\
I=56\end{array}$ \\
\hline
\end{tabular}

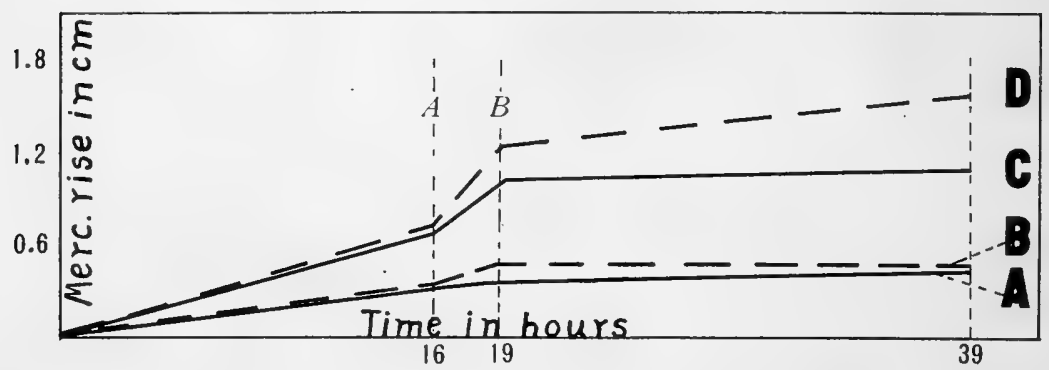

FIG. 6.-Oxidation of pyrogallol by precipitated oxidases from healthy and diseased bark, with and without gelatine, shaken only during period from $A$ to $B$ : A, precipitate from healthy bark without gelatine; B, precipitate from healthy bark with gelatine; C, precipitate from diseased bark without gelatine; D, precipitate from diseased bark with gelatine.

precipitates whose air dry weights, determined by the use of tared filters, were as follows:

\begin{tabular}{|c|c|c|}
\hline & $\begin{array}{l}\text { From extract of } \\
\text { healthy bark }\end{array}$ & $\begin{array}{l}\text { From extract of } \\
\text { diseased bark }\end{array}$ \\
\hline $\begin{array}{l}\text { Fraction } 1 \ldots \ldots \ldots \ldots \\
\text { Fraction } 2 \ldots \ldots\end{array}$ & $\begin{array}{l}0.0099 \mathrm{gm} . \\
0.0080\end{array}$ & $\begin{array}{l}0.0532 \mathrm{gm} . \\
0.0164\end{array}$ \\
\hline Total. & 0.0179 & 0.0696 \\
\hline
\end{tabular}

The greater amount of precipitate from diseased bark may or may not be directly connected with its greater oxidase activity. 
Further study is necessary to show the facts. A test of these precipitates with pyrocatechin showed that while the 2 fractions from healthy bark are about equal in oxidizing power the first fraction from diseased bark is I I times as active as the second (fig. 7).

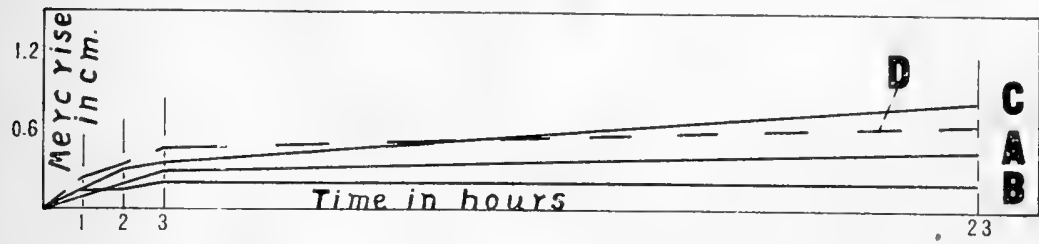

FIG. 7.-Oxidation of pyrocatechin by precipitated oxidases from healthy bark, without gelatine: A, fraction I; B, fraction 2; C, fractions I and 2 tested together; D, sum of fractions I and 2 tested separately.

Other precipitates were prepared using $25 \mathrm{cc}$. of alcohol for the first fraction and $100 \mathrm{cc}$. more for the second. The oxidase activity of these, tested separately and combined, with and without gelatine, is shown in table XIX.

\section{TABLE XIX}

OXIDASE ACTIVITY OF FIRST AND SECOND FRACTIONS FROM BARK EXTRACT TESTED SEPARATELY AND COMBINED; TEMPERATURE $29.5-30.0^{\circ} \mathrm{C}$.

\begin{tabular}{|c|c|c|c|c|}
\hline \multirow[b]{2}{*}{ BARK EXTRACT } & \multicolumn{2}{|c|}{ WITHOUT GELATINE } & \multicolumn{2}{|c|}{ WITH GELATINE } \\
\hline & $\begin{array}{l}\text { Sum of fractions } \\
\text { I and } 2 \text { tested } \\
\text { separately }\end{array}$ & $\begin{array}{c}\text { Fractions } \mathrm{I} \text { and } z \\
\text { combined }\end{array}$ & $\begin{array}{l}\text { Sum of fractions } \\
\text { I and } 2 \text { tested } \\
\text { separately }\end{array}$ & $\begin{array}{l}\text { Fractions I and } 2 \\
\text { combined }\end{array}$ \\
\hline $\begin{array}{l}\text { Healthy, after } 23 \text { hours.... } \\
\text { Diseased, "6 }{ }_{3} 866\end{array}$ & $\begin{array}{l}0.65 \\
\text { I. } 82\end{array}$ & $\begin{array}{l}0.84 \\
2.00\end{array}$ & $\begin{array}{l}0.76 \\
2.64\end{array}$ & $\begin{array}{l}0.84 \\
3.06\end{array}$ \\
\hline
\end{tabular}

The mechanism by which gelatine increases the oxidase activity is not clear. It is evidently not through buffer action, as shown by its lack of effect on the hydrogen ion concentration (table XVII, figs. 8,9 , I0). Special tests showed that there was no hydrolysis of the gelatine to amino acids, in either healthy or diseased bark, which would increase its buffer effect. If gelatine is effective through its action as a protective colloid, its effect in this direction must be very complex, as shown by its difference in effect on bark mixtures and precipitated oxidases. 


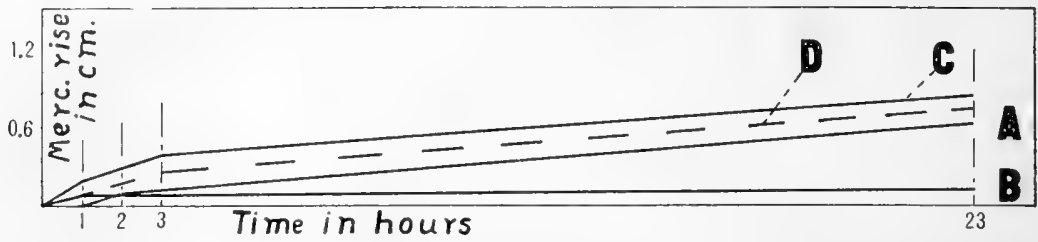

FIG. 8.-Oxidation of pyrocatechin by first and second fractions of healthy bark, with gelatine (for explanation of lettering see legend for fig. 7).

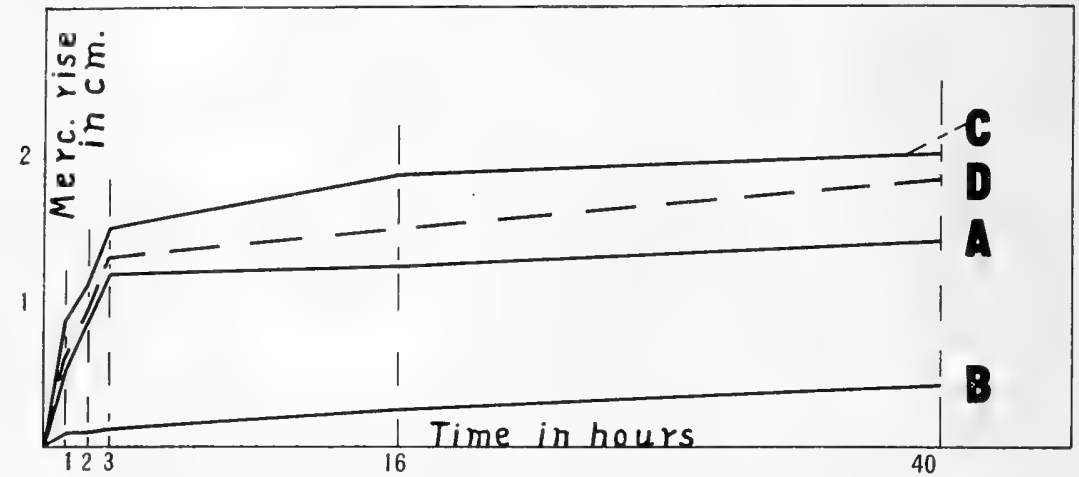

FIG. 9.-Oxidation of pyrocatechin by first and second fractions from diseased bark, without gelatine (for explanation of lettering see legend for fig. 7); points of plotting marked by vertical broken lines.

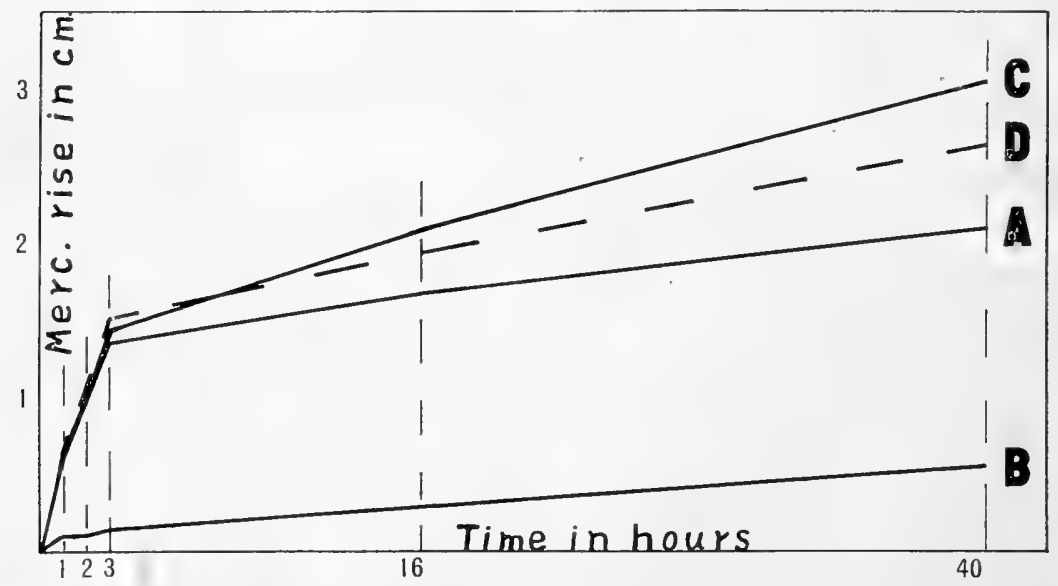

FIG. I0.-Oxidation of pyrocatechin by first and second fractions from diseased bark, with gelatine (for explanation of lettering see legend for fig. 7); points of plotting as in fig. 9 . 
The difference in the effect of gelatine and of gum arabic on oxidation by healthy bark may depend on differences in the colloidal solutions they form. An artificial oxidase prepared by Dony-Henault (r8) from manganese formate, sodium bicarbonate, and gum arabic could be destroyed by heat; but one prepared by Trillat (33) from albumin and manganese could not be so destroyed. Bayliss $(6$, p. 585$)$ thinks the difference here "clearly depends on the nature of the emulsion colloid in association with the metal." On the other hand, what little increase in oxidation gum arabic produces may be due to an oxidase naturally present in it (Bourquelot 7), although an experiment designed to test this question gave negative results. One per cent gum arabic plus I per cent pyrogallol, and pyrogallol alone, were placed in separate oxidase tubes and shaken twice during each 24 hours. At the end of 3 days the mercury rise was $0.32 \mathrm{~cm}$. in the first case and $0.20 \mathrm{~cm}$. in the second, a difference almost within the limits of error in reading the manometers.

The data given in table XIX show that when the precipitate is collected in 2 fractions, these fractions have a greater oxidase activity if combined than if used separately. This condition seems to be about the same as that described by BACH and CHоDAT (4) for Lactarius vellereus. They found that by the fractional precipitation of an aqueous solution of the oxidase of this fungus, by alcohol, 2 fractions could be obtained possessing markedly different properties. The first of these was almost insoluble in 40 per cent alcohol and had the properties of a weak oxidase; the second was soluble in 40 per cent alcohol but insoluble in pure alcohol and had no oxidizing powers. This fraction, however, was found to impart greater activity to hydrogen peroxide as an oxidizing agent; it was also found to increase markedly the oxidizing powers of the first fraction. The chief difference between this situation and that found in the work with apple bark is that in the latter case the first fraction has more than a weak oxidase activity, while the second, possibly because of incomplete separation of the fractions, is not entirely without it. No tests have been made of the behavior of the second fraction toward hydrogen peroxide. 
OXIDASE ACTIVITY OF THE FUNGUS IN PURE CULTURE.-A fungus powder was prepared according to the method employed by REED (29) from mats of Nummularia mycelium grown in the potato extract medium described by DUGGar (I9). A test with 3 Bunzell tubes using 0 . I gm. of fungus powder, $4 \mathrm{cc}$. of I per cent pyrogallol, and I cc. of water gave after 4 days an average mercury rise of $2.35 \mathrm{~cm}$. Quantitative tests on the medium in which the fungus had grown showed "oxidase" present there also. From these results it appears probable that the greater oxidase activity of diseased bark is due to a summation of the oxidase activity of normal bark and of the canker fungus itself. This may also account for the difference in behavior of the oxidases of the two.

The general conclusion to be drawn from the preceding data is that diseased bark has greater oxidase activity than healthy bark, probably because of lower acidity and greater degree of dispersion of the oxidizing agent, and because of an actually greater oxidase content. The lower tannin content of diseased bark (see macrochemical work) may also be a contributing factor, since tannins are known to cause inhibition of oxidase action. This factor is probably eliminated when precipitated oxidases are used.

In reference to the Bunzell apparatus it may be said that while it gives valuable comparative measurements of oxidase activity, those using it must realize its limitations. Conditions within it are artificial; with reference to hydrogen ion concentration, and probably other inhibiting factors, they are unstable and continually moving toward an equilibrium which, so far as we know; does not coincide with the equilibrium obtaining in the plant.

\section{Catalase}

Determinations of catalase activity (table $\mathrm{XX}$ ) were made on I 2 samples of bark, of which nos. 9 and to form a set from one tree and nos. 13 to 20 a set from another tree. Nos. 3 and 4 each came from different trees and are the ones used for most of the oxidase work reported in this paper. They were about I year old when tested for catalase. The other samples were freshly prepared for this work in December r9I7 and January 1918. The limbs from which they came were carefully cleaned to remove lichens, 
Pleurococcus, etc., since microchemical work had shown that such growths have a high catalase activity. The bark was then shaved off, ground in a meat chopper, and allowed to dry on filter paper at room temperature. In the case of samples 9, I0, I4, I6, I8, and 20 , calcium carbonate was added during the grinding process at the rate of $0.5 \mathrm{gm}$. to each $10 \mathrm{gm}$. of unground bark, to prevent destruction of catalase by the acids of the bark (2) or of the hydrogen peroxide used. The dried bark was finally ground to a powder and only that part used which passed through an 80-mesh sieve.

TABLE XX

Catalase activity of apple Bark

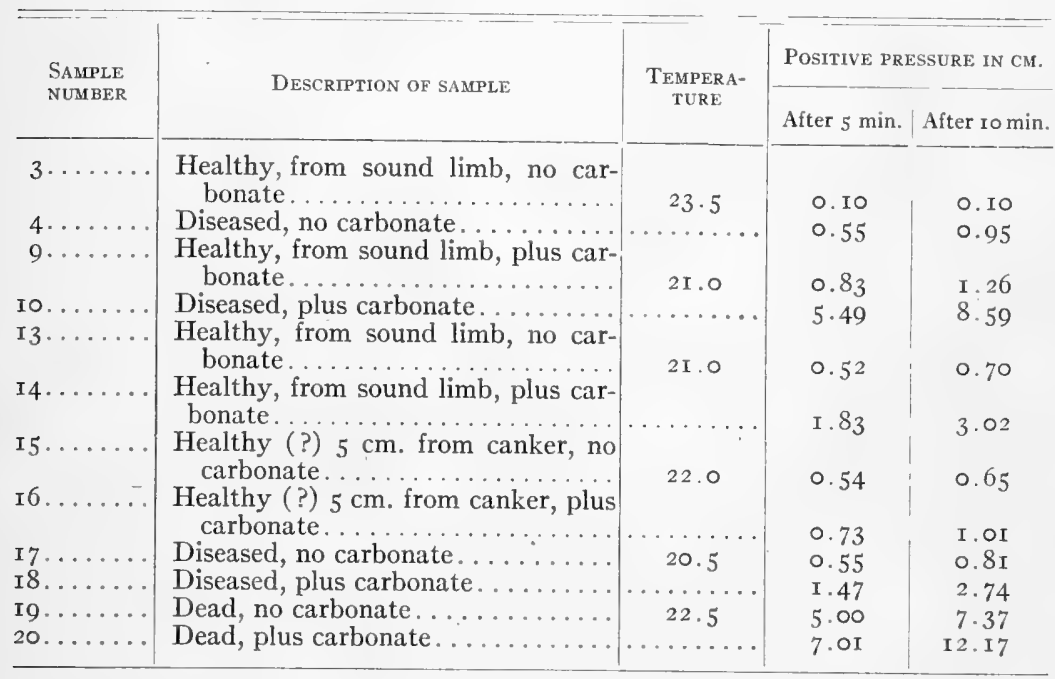

Tests were made at room temperature by means of the simplified Bunzell apparatus, using 0.03 or $0.10 \mathrm{gm}$. of bark powder, I cc. of water, and 4 cc. of 25 per cent hydrogen peroxide. After the experiment was set up the apparatus was allowed to stand for half an hour, when the manometers were closed and the solutions mixed. The apparatus was shaken for ro seconds at the end of each minute and readings taken after 5 and ro minutes. All tests were made in duplicate or quadruplicate, a water blank being included for temperature corrections as in the oxidase work. 
A test for catalase was run also on the fungus powder previously mentioned, using $0.03 \mathrm{gm}$. in each tube and calculating the results to the basis of $0.10 \mathrm{gm}$. The average mercury rise (positive pressure) produced in 3 tubes was $1.65 \mathrm{~cm}$. in 5 minutes and $2.57 \mathrm{~cm}$. in ro minutes, or, calculated to the basis of $0.10 \mathrm{gm}$., $5.49 \mathrm{~cm}$. in 5 minutes, and $8.55 \mathrm{~cm}$. in Io minutes. It is worthy of note that a powder prepared from Nummularia mycelium grown in Raulin's solution, which is acid to litmus, showed no catalase activity. Experiments with different amounts of material showed that the positive pressure varies directly with the amount of material used. It was deemed legitimate, therefore, to calculate all results to the basis of 0 . Io gm. of bark powder, and the figures for final tabulation were so calculated.

The results for samples I4, I6, I8, all from the same tree, show that diseased bark (sample I8) had more than twice the catalase activity of seemingly healthy bark $5 \mathrm{~cm}$. away from the canker (sample I6), but only nine-tenths of that of bark from a sound unaffected limb on the same tree (sample I4). Dead cankered bark from this tree (sample 20) had 4 times the catalase activity of healthy bark, I 2 times that of seemingly healthy bark next the canker, and nearly 5 times that of diseased bark. In the case of samples 9 (healthy) and ro (diseased), the results are reversed, since the diseased had a catalase activity nearly 7 times greater than that of the healthy bark. The reason for the discrepancy between these two sets is not clear. The high catalase activity of sample no. Io can hardly have been due to the presence of lichens, etc., or of an admixture of really dead bark, for precautions were taken when the samples were removed to avoid these sources of error. From the present data the only conclusion that can be drawn is that diseased bark from different trees varies considerably in its catalase activity, and that in general the more completely the bark is destroyed by the fungus the greater is its catalase activity. This condition is probably to be explained by the presence in the diseased bark of considerable amounts of mycelium which, as shown, produces a catalase of its own.

The seemingly healthy bark near the canker when compared with sound and with diseased bark appears to form an exception 
in the series. Its catalase activity is less than that of either of the others and seems to be less affected by tissue acids when no carbonate is added. It is possible that near the canker the host's catalase is injured by materials from the fungus, even in advance of actual invasion by the hyphae. The fungus catalase may not appear here at all, but only later in the diseased bark, and in increasing amounts as the amount of mycelium increases.

The oxidase activity of samples I3, I5, I 7, I9, together with the catalase activity of samples I4, I6, I8, 20, identical with them except for the addition of carbonate, are given in table XXI.

TABLE XXI

Catalase activity of APple Bark

\begin{tabular}{|c|c|c|}
\hline \multirow{2}{*}{ DESCRIPTION OF SAMPLE } & \multicolumn{2}{|c|}{$\begin{array}{l}\text { MANOMETER READINGS EXPRESSED } \\
\text { IN CM. OF MERCURY USING O. I } \\
\text { GM. OF BARK POWDER }\end{array}$} \\
\hline & Catalase & Oxidase \\
\hline 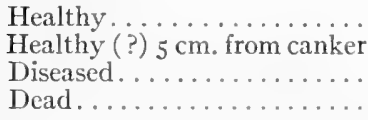 & $\begin{array}{r}3.02 \\
1.01 \\
2.50 \\
12.17\end{array}$ & $\begin{array}{l}\text { I. I6 } \\
\text { I. } 47 \\
\text { I. } 95 \\
\text { 0.88 }\end{array}$ \\
\hline
\end{tabular}

It will be seen that there is a gradual increase in oxidase activity from healthy to diseased bark, but a marked decrease in the case of dead bark. The catalase is considerably lower in apparently healthy bark near a canker than in the bark of an unaffected limb, but very much higher in the bark killed by the fungus than in bark from a healthy limb.

\section{Microchemical analysis}

Tests for oxidase, peroxidase, and catalase were made on fresh bark, all others on bark preserved in 50 per cent alcohol. The results are given in table XXII.

In making the tests for oxidase (direct action) and peroxidase (indirect action), the brownish purple color due to oxidation of benzidine was found most marked at first, in both healthy and diseased bark, in a zone 2 or 3 cells wide just inside the cork and in the pith rays. Later it came to about the same intensity over 
the whole section. Catalase, judging by evolution of gas when $\mathrm{H}_{2} \mathrm{O}_{2}$ was added, was evenly distributed in all the tissues. Tests with $\mathrm{FeCl}_{3}$ on sections of bark successively farther and farther

\section{TABLE XXII}

RESULTS OF MICROCHEMICAL TESTS ON HEALTHY AND DISEASED BARK

\begin{tabular}{|c|c|c|c|}
\hline \multirow{2}{*}{ Substance } & \multirow{2}{*}{ REAGENT } & \multicolumn{2}{|c|}{ REACTION } \\
\hline & & Healthy & Diseased \\
\hline Cellulose....... & $\begin{array}{l}\text { IKI and } 75 \text { per } \\
\text { cent } \mathrm{H}_{2} \mathrm{SO}\end{array}$ & $t+$ & + \\
\hline Pectin. & Ruthenium red & $\begin{array}{l}T+1 \\
+\end{array}$ & $\begin{array}{l}+ \\
+\end{array}$ \\
\hline Lignin... . & $\begin{array}{l}\text { Phloroglucin and } \\
\mathrm{HCl}\end{array}$ & + in bast & + in bast \\
\hline Tannin............ & Ferric chloride & ++ & + \\
\hline Nitrates.......... & $\begin{array}{l}\text { Diphenylamine in } \\
75 \text { per cent } \mathrm{H}_{2} \mathrm{SO}_{4}\end{array}$ & & \\
\hline Fats......... & Sudan III & $\begin{array}{l}+ \text { Especially in } \\
\text { parenchyma next } \\
\text { to cork }\end{array}$ & $\begin{array}{c}+ \text { Same as for } \\
\text { healthy bark }\end{array}$ \\
\hline Calcium (crystals)... & 50 per cent acetic & + + Crystals sol- & ++ Crystals sol- \\
\hline $\begin{array}{r}\text { Calcium oxalate (crys- } \\
\text { tals) } \ldots \ldots \ldots \ldots \ldots\end{array}$ & Oxalic acid & $\begin{array}{l}+ \text { CaSO }_{4} \text { tormed } \\
+ \text { changed }\end{array}$ & $\begin{array}{l}++\mathrm{CaSO}_{4} \text { lormed } \\
++ \text { Crystals not } \\
\text { changed }\end{array}$ \\
\hline Direct reducing sugars & Flückigers reagent & + & ++ \\
\hline 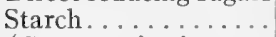 & IKI & ++ & + \\
\hline$\left\{\begin{array}{l}\text { Cyanogenic gluco- } \\
\text { side, probably }\end{array}\right.$ & $\begin{array}{l}\text { Picric acid and } \\
\mathrm{Na}_{2} \mathrm{CO}_{3}\end{array}$ & 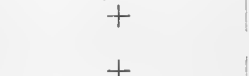 & \\
\hline $\begin{array}{c}\text { amygdalin ........ } \\
\text { Oxidase (direct action) }\end{array}$ & $\begin{array}{l}\text { Berlin blue reaction } \\
\text { I per cent benzidine } \\
\text { in } 50 \text { per cent } \\
\text { alcohol }\end{array}$ & $\begin{array}{l}+ \\
+\end{array}$ & + \\
\hline $\begin{array}{l}\text { Peroxidase (indirect } \\
\text { action) } \ldots . . . . .\end{array}$ & $\begin{array}{l}\text { I per cent benzidine } \\
\text { and } \mathrm{H}_{2} \mathrm{O}_{2}\end{array}$ & + & + \\
\hline Catalase.......... & $\mathrm{H}_{2} \mathrm{O}_{2}$ & + & + \\
\hline
\end{tabular}

distant from the badly browned region showed steadily increasing amounts of tannin. Pectin seemed to be present in about equal amounts in both healthy and diseased tissues.

\section{Macrochemical analysis}

Six samples were analyzed. The analytical methods used for 4 of them are based on those employed by Koch for the quantitative study of animal and plant tissues (21, pp. 199-207). The difference in material required minor variations from these methods, but it is not thought necessary to describe them here. The other 
2 were analyzed according to a method devised by KRAYBILL (unpublished work) in a study of the chemical composition of tomato plants. Material for 4 of the samples, healthy I and 2 and diseased I and 2, was taken from 8-10 cm. apple limbs cut in January at the Missouri State Fruit Experiment Station, and shipped from there by express. As soon as these samples arrived they were prepared as follows: bark designated as "healthy" was removed from sound limbs with a box scraper and cut into pieces half an inch square; about I $50 \mathrm{gm}$. were then weighed quickly on a torsion balance to hundredths of a gram and put into enough redistilled alcohol (95 per cent) to give an alcohol concentration of approximately 85 per cent. The bottles containing the samples were then set into a steam bath until the alcohol came to a boil, then on top for I hour longer, to inactivate the enzymes.

Bark designated as "diseased" was taken from 8-10 cm. limbs showing well developed but not old cankers, usually about $45 \mathrm{~cm}$. long. A strip of moist browned bark $2-3 \mathrm{~cm}$. wide around the outside of the canker was removed with the box scraper, cut up, weighed, and preserved as described. This material usually contained small portions of the seemingly healthy bark outside of the canker, but never any part of the black dead material that often covers the central part of the cankered areas. Healthy samples 3 and 4 were taken from a $7 \mathrm{~cm}$. limb cut in April when the bark peeled easily, to avoid removing small shavings of wood along with the bark, as was inadvertently done in the case of healthy samples I and 2 (see discussion of table XXV). Healthy samples 3 and 4 were not extracted with hot alcohol and ether as in the method described by HaRver (2I); instead the alcohol for preserving was filtered into a rooo cc. flask and made up to volume. One-twentieth aliquots were then pipetted off into small beakers, evaporated to a syrup, and used later for dry weight and other estimations. The partly extracted bark was dried as described for the other samples, weighed, ground, allowed to come to air dry condition, and one-twentieth aliquots weighed out as before. This method of handling the material is much shorter than the $\mathrm{KoCH}$ method and is very satisfactory if one is not interested in the distribution of substances in the various fractions. 
DRY WEIGHT.--One-tenth or one-twentieth aliquots, in tared crucibles or beakers, were brought to constant weight in a vacuum desiccator after intermittent drying for various lengths of time at about $100^{\circ} \mathrm{C}$.

Nitrogen.-Estimations were made by the Kjeldahl-Gunning method, modified to include the nitrogen of nitrates. For healthy samples I and 2 and diseased samples I and 2 estimations were made separately on fractions 2 and 3 ; no nitrogen was found in fraction 2. Estimations for healthy samples 3 and 4 were made on one-twentieth of the alcohol extract combined with one-twentieth of the partly extracted bark.

CARBohydrates.- Healthy samples I and 2, diseased samples I and $2:$ in the case of fraction 2, direct reducing sugars, and reducing sugars after mild hydrolysis, were estimated by the Bertrand volumetric method and calculated as dextrose by use of the Munson and WALKER tables (34). The more important details of manipulation, including precipitation of non-sugars, are given by CuLPepper, Foster, and Caldwell (I6). The polysaccharides in fraction 3 were estimated as dextrose, but after 2.5 instead of 5 hours' hydrolysis (I6).

Healthy samples 3 and 4: one-twentieth of the air dry, partly extracted bark was further extracted on a filter with about $200 \mathrm{cc}$. of water at $40^{\circ} \mathrm{C}$., the filtrate being collected in a beaker containing one-twentieth of the alcohol extract. Estimation of sugars and polysaccharides in the combined extracts were then made as already described. The results of the analysis are given in tables XXIII and XXIV and summarized in table XXV.

The most important differences shown in the tables, as between healthy samples I and 2 and diseased samples I and 2, are as follows: diseased tissue contains 3.23 per cent more dry matter than healthy, although here much depends on the manner in which the sample is taken; on the basis of dry weight, fraction I is larger in the diseased by $4.5^{6}$ per cent (nearly doubled), indicating a synthesis of lipoids by the fungus; fraction 3 , the alcohol-waterinsoluble residue, is larger by 1.83 per cent, while fraction 2, containing the alcohol-water-soluble substances, is smaller by 6.27 per cent. These results are strikingly similar to those found by 
Culpepper, Foster, and Caldwell (I6), working with black rot of apples, caused by Sphaeropsis malorum. The increase in total

TABLE XXIII

RESUlTS OF ANALYSIS OF HEALTHY BARK

\begin{tabular}{|c|c|c|c|c|}
\hline Material & $\begin{array}{l}\text { Percentage wet } \\
\text { weight }\end{array}$ & $\begin{array}{l}\text { Percentage wet } \\
\text { weight }\end{array}$ & $\begin{array}{l}\text { Percentage dry } \\
\text { weight }\end{array}$ & $\begin{array}{l}\text { Percentage dry } \\
\text { weight }\end{array}$ \\
\hline Total solids. & $\begin{array}{l}\text { Sample I } \\
5 \mathrm{I} .55\end{array}$ & $\begin{array}{l}\text { Sample } 2 \\
5 \mathrm{I} \cdot 5 \mathrm{O}\end{array}$ & Sample I & Sample 2 \\
\hline$" \approx F_{I}$. & 2.56 & 2.59 & 4.97 & 5.04 \\
\hline $\begin{array}{lll}\text { " } & \mathrm{F}_{2}\end{array}$ & 14.84 & 13.26 & 28.79 & 25.85 \\
\hline Total nitrogen. & 34.14 & $35 \cdot 45$ & $66.2 \mathrm{I}$ & 69.08 \\
\hline $\begin{array}{l}\text { Total nitrogen.......... } \\
\text { Direct reducing sugars. }\end{array}$ & 0.23 & 0.23 & 0.45 & 0.46 \\
\hline Reducing sugars after mild & 1.58 & I. 60 & 3.06 & 3.13 \\
\hline $\begin{array}{l}\text { hydrolysis................... } \\
\text { Reducing sugars after strong }\end{array}$ & 0.55 & 0.54 & I. 07 & 1.05 \\
\hline $\begin{array}{l}\text { hydrolysis } F_{I} \text { and } F_{2} \ldots \\
\text { Reducing sugars after strong }\end{array}$ & I. .07 & 0.22 & 2.08 & 1.71 \\
\hline $\begin{array}{l}\text { hydrolysis } \mathrm{F}_{3} \ldots \ldots \ldots \ldots \\
\text { Reducing sugars after strong }\end{array}$ & 7.40 & 7.56 & $\mathrm{I} 4 \cdot 35$ & 14.74 \\
\hline hydrolysis, total & 8.47 & $7 \cdot 78$ & I 6.43 & I 6.45 \\
\hline Total solids. & $\begin{array}{l}\text { Sample } 3 \\
46.3_{3}\end{array}$ & $\begin{array}{l}\text { Sample } 4 \\
46.24\end{array}$ & Sample 3 & Sample 4 \\
\hline Total nitrogen . . . . . . . . . . & 0.217 & $0.23 \mathrm{I}$ & 0.46 & 0.50 \\
\hline $\begin{array}{l}\text { Direct reducing sugars. .... } \\
\text { Reducing sugars after mild }\end{array}$ & $0.9 \mathbf{I}_{5}$ & 0.949 & I.96 & 2.05 \\
\hline $\begin{array}{l}\text { hydrolysis................ } \\
\text { Reducing sugars after strong }\end{array}$ & 0.634 & $0.66 i^{\circ}$ & I. 72 & I. 45 \\
\hline hydrolysis.............. & $7 \cdot 5^{24}$ & 7.189 & I6.20 & 16.55 \\
\hline
\end{tabular}

\section{TABLE XXIV}

RESULTS OF ANALYSIS OF DISEASED BARK

\begin{tabular}{|c|c|c|c|c|}
\hline Material & $\begin{array}{c}\text { Sample I } \\
\text { Percentage } \\
\text { wet weight }\end{array}$ & $\begin{array}{c}\text { Sample } 2 \\
\text { Percentage } \\
\text { wet weight }\end{array}$ & $\begin{array}{l}\text { Sample I } \\
\text { Percentage } \\
\text { dry weight }\end{array}$ & $\begin{array}{c}\text { Sample } 2 \\
\text { Percentage } \\
\text { dry weight }\end{array}$ \\
\hline 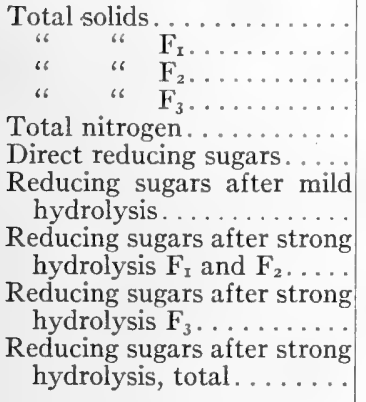 & $\begin{array}{r}54.29 \\
4.69 \\
\text { I I. } 52 \\
38.07 \\
0.45 \\
\text { I. } 42 \\
0.66\end{array}$ & $\begin{array}{r}55.12 \\
5.77 \\
\text { II } .52 \\
37.94 \\
0.45 \\
1.56 \\
0.59 \\
0.38 \\
8.84\end{array}$ & $\begin{array}{r}8.64 \\
21.21 \\
70.16 \\
0.83 \\
2.62 \\
\\
1.22 \\
0.23 \\
\text { I6.2I } \\
\text { I6.44 }\end{array}$ & $\begin{array}{r}\text { I0.47 } \\
20.89 \\
68.80 \\
0.81 \\
2.83 \\
1.07 \\
0.70 \\
\text { I6.04 } \\
\text { I6.74 }\end{array}$ \\
\hline
\end{tabular}


nitrogen in diseased bark may be due to fixation by the fungus or to a withdrawal of nitrogen from the surrounding tissue. Further data are necessary before a conclusion can be reached. CuLPEPPER, FosTeR, and CALDWELL found protein-nitrogen content of fraction 2 for diseased apples larger than for normal ones, but the total nitrogen for the whole tissue smaller for the former than for the latter.

TABLE XXV

SUMmaRY

\begin{tabular}{|c|c|c|c|c|c|c|}
\hline \multirow{2}{*}{ Material } & \multicolumn{3}{|c|}{ AVERAGE PERCENTAGE WET WEIGHT } & \multicolumn{3}{|c|}{ AVERAGE PERCENTAGE DRY WEIGHT } \\
\hline & $\begin{array}{l}\text { Healthy I } \\
\text { and } 2\end{array}$ & $\begin{array}{l}\text { Healthy } 3 \\
\text { and } 4\end{array}$ & $\begin{array}{l}\text { Diseased I } \\
\text { and } 2\end{array}$ & $\begin{array}{c}\text { Healthy I } \\
\text { and } 2\end{array}$ & $\begin{array}{l}\text { Healthy } 3 \\
\text { and } 4\end{array}$ & $\begin{array}{l}\text { Diseased I } \\
\text { and } 2\end{array}$ \\
\hline Total solids... & 5 I .53 & 46.19 & $54 \cdot 70$ & $\ldots \ldots$ & & $\ldots$ \\
\hline$\because \quad \mathrm{F}_{\mathrm{x}} \ldots$ & $2.5^{8}$ & $\ldots \ldots$ & 5.23 & 5.00 & & $9 \cdot 5^{6}$ \\
\hline $\mathrm{F}_{2} \ldots$ & 14.05 & & II .52 & $27 \cdot 32$ & & 21.05 \\
\hline " " $\mathrm{F}_{3} \ldots$ & 34.00 & $\ldots \ldots$ & $37 \cdot 57$ & 67.65 & & 69.48 \\
\hline Total nitrogen.......... & 0.23 & 0.24 & 0.45 & 0.46 & $0.4^{8}$ & 0.82 \\
\hline Direct reducing sugars.... & I. 59 & 0.93 & I. 49 & 3.00 & 2.00 & 2.73 \\
\hline $\begin{array}{l}\text { Direct reducing sugars after } \\
\text { mild hydrolysis. . . . . . . }\end{array}$ & 0.55 & 0.65 & 0.62 & r. 06 & I. 59 & I. 15 \\
\hline $\begin{array}{l}\text { Direct reducing sugars after } \\
\text { strong hydrolysis....... }\end{array}$ & 8.12 & $7 \cdot 35$ & 9.08 & I6. 44 & I6. 68 & 16.59 \\
\hline
\end{tabular}

Results with healthy samples 3 and 4 furnish little of additional interest. They show, however, that as far as total nitrogen and starch are concerned, the small amount of wood in the other 2 healthy samples had no effect on the results. The difference in the case of dry weight and reducing sugars before and after hydrolysis is probably due to the fact that samples 3 and 4 were taken from a limb cut early in the growing season, while samples I and 2 were taken from limbs cut in the dead of winter.

\section{Estimation of tannin}

The method used was that of Löwenthal, as modified by Proctor (34, p. I50). Material for analysis was taken from 8-I $2 \mathrm{~cm}$. Ben Davis limbs cut in November, December, and January. The bark was cut off as already described, ground in a meat grinder, and transferred to a glass moist chamber at once. About Io gm. were then weighed out and set to boil in $400 \mathrm{cc}$. of 
water as required by the LöweNTHAL method; at the same time duplicate samples were taken for moisture determination. Whatever may have been the errors introduced by this method, the agreement between duplicates taken for moisture determination was very close in most cases, as is shown in table XXVI.

\section{TABLE XXVI}

Percentage of Dry Matter in DUplicate samples of VARIOUS LOTS OF BARK ANALYZED

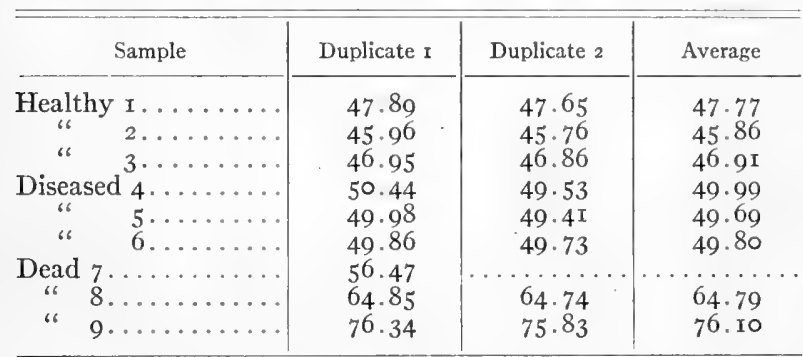

The results of the analysis of 9 different samples of bark are shown in table XXVII.

\section{TABLE XXVII}

Percentage of tannin in healthy and Diseased APPLE BARK

\begin{tabular}{|c|c|}
\hline Description of sample & $\begin{array}{l}\text { Tannin (percent- } \\
\text { age dry weight) }\end{array}$ \\
\hline 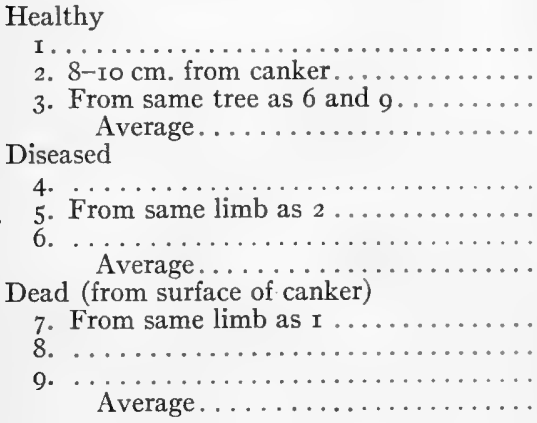 & $\begin{array}{l}2.49 \\
3.56 \\
2.93 \\
2.99\end{array}$ \\
\hline
\end{tabular}

The LöwenthaL method probably determines merely the easily water-soluble tannins, but fails to reach those tied up with 
the suberin. If suberin is for any reason more abundant in the diseased bark, an error would thus be introduced which might invalidate any comparisons based on the results obtained. Subject to this possible correction the results shown in table XXVII confirm those obtained in the microchemical analysis; that is, they show a progressive decrease in tannin as the bark is more and more affected by the disease. Healthy bark was found to contain on the average 4.06 per cent of tannin, diseased 2.99, and dead 0.97 . If sample I healthy, which gave a high figure, and sample 7 dead, which gave a low figure, be eliminated, the averages become healthy $3.5 \mathrm{I}$, diseased 2.99, dead I.33. The figures for samples 3,6 , and 9 , all from the same tree, are healthy 3.38 , diseased 2.93 , dead I.5I. There is undoubtedly a difference between bark from a sound limb and seemingly healthy bark from a limb that is badly cankered. The latter is usually slightly browned throughout when first cut off and rapidly becomes reddish brown on exposure to air. Really healthy bark under such conditions shows only a slight browning.

Whatever the results with apple bark may mean, they are not in agreement with the statement made by KERR (see Cook and WiLson, 15, p. 26, footnote) that because of the greater stability of tannin and the disappearance of other constituents "all decayed wood and bark give higher tannin contents, no matter what causes the decay." If confirmed by further analyses they would indicate a different relation between host and parasite with reference to tannin in the case of blister canker than obtained in any of the cases studied by KERR. Leaching of tannin may account for the low percentage found in dead apple bark, as suggested by the chemist of the Chestnut Tree Blight Commission (15, p. 6) for old cankers of chestnut blight, but can hardly be responsible for the condition found in diseased bark.

\section{Summary}

I. Measurements with the simplified Bunzell apparatus show that apple bark attacked by Nummularia discreta causes about twice as much oxidation of pyrogallol, pyrocatechin, guaiacol, and benzidine as does healthy bark. 
2. The gradual slowing down of oxidation in the Bunzell apparatus is shown to be due, in part at least, to increasing hydrogen ion concentration, brought about by the oxidation process itself. The equilibrium reached in the oxidase apparatus seems to be a false one, which can be disturbed by the addition of either fresh oxidase reagent or plant material. When tested by the formula for a unimolecular reaction, the oxidase reaction gives values for $k$, which indicate clearly a linear relationship between time and amount of change and suggest that the oxidase is a catalytic agent.

3. The hydrogen ion concentration of diseased bark $\left(P_{\mathrm{B}}=5.6 \mathrm{I}\right)$ is definitely less than that of healthy bark $\left(P_{\mathrm{H}}=5 \cdot \mathrm{I}_{5}\right)$. Work with buffer solutions shows that this difference is not great enough to account for all of the difference in the oxidase activity of the two kinds of material. When mixtures of the two are brought to the same hydrogen ion concentration by means of buffer solutions, diseased bark still shows greater oxidase activity.

4. The temperature and duration of drying have an effect on the acidity and the oxidase activity of both healthy and diseased bark.

5. Eight-tenths per cent gelatine increases the oxidase activity of both kinds of bark. This may be due to the action of gelatine as a protective colloid which prevents precipitation of the "oxidase." It is not due to buffer action.

6. The concentration of hydrogen ion necessary or complete inhibition of oxidase activity of healthy bark lies between 3.55 and $3.80 \times \mathrm{IO}^{-4}$; for that of diseased bark between 3.55 and $4.27 \times \mathrm{IO}^{-4}$.

7. Oxidation in the apparatus comes to an end only after several days instead of after a few hours, as stated by BunzeLL.

8. When the "oxidase" is precipitated in 2 fractions, the first has greater oxidizing power than the second, and the 2 combined have slightly greater oxidizing power than when tested separately.

9. Catalase determinations gave the following results: healthy $3.02(\mathrm{~cm}$. positive pressure), seemingly healthy $5 \mathrm{~cm}$. from the canker I.OI, diseased 2.74, dead I2.I7; results from oxidase determinations for the same stages were I.I6, I.47, I.95, I.85 (cm. negative pressure). These results show some discrepancies, but justify the general statement that the more severely the bark 
is attacked by the fungus the greater is its catalase activity, and that catalase activity in part is in indirect ratio to oxidase activity.

Io. Microchemical tests indicate, for diseased bark, a partial disintegration of cellulose, a disappearance of cyanogenic glucoside, and a lower content of starch, calcium oxalate, and tannins.

II. Macrochemical analyses show that diseased bark has a higher percentage of dry matter, lipoids, alcohol-water-insoluble residue, and total nitrogen, but a lower percentage of alcohol-watersoluble material than healthy bark. The percentage of carbohydrates in both tissues seems to be about the same. Differences in tannin content are definite but not large. Sound healthy bark contains more than diseased bark and diseased bark more than dead bark from the surface of the canker.

I2. The greater oxidase activity of diseased bark is probably due to the combined activity of the oxidases of fungus and host, lower acidity, and possibly to a greater degree of dispersion of the oxidizing agent. The lower tannin content of diseased bark may also be a contributing factor.

The writer wishes to acknowledge his indebtedness to Dr. William Crocker, Dr. F. C. Koch, and Dr. Sophia H. ECKERSON for valuable suggestions and criticism during the course of the investigation. Thanks are due to Dr. Paul Evans of the Missouri State Fruit Experiment Station for bark material used in the experiments.

U.S. Department of Agriculture

WAShington, D.C.

\section{LITERATURE CITED}

I. Allard, H. A., Some properties of the virus of the mosaic disease of tobacco. Jour. Agri. Research 6:649-674. I9I6.

2. Appleman, Charles O., Some observations on catalase. Bot. Gaz. 50:I82-I92. I9IO.

3. Atkins, W. R. G., Recent researches in plant physiology. London. I9I6.

4. Bach, - , and Chodat, O. R., Untersuchungen über die Rolle der Peroxyde in der Chemie der lebenden Zelle: IV, Über Peroxydase Ber. Deutsch. Chem. Gesell. 36:600-605. I903.

5. Battelli, F., and Stern, L., Die Oxydationsfermente. Ergeb. Physiol. 12:96-268. r912. 
6. Bayliss, W. M., Principles of general physiology. London. I9I 5.

7. Bourquelot, Emile, Présence de ferment oxydant dans quelques substances médicamenteuses. Compt. Rend. Soc. Biol. 49:25-28. I897.

8. Bovie, W. T., A direct reading potentiometer for measuring and recording the actual and the total reaction of solutions. Jour. Med. Research 33:301. I9I5.

9. Bunzell, H. H., The measurement of the oxidase content of plant juices. U.S. Dept. Agric. Bur. Pl. Ind., Bull. 238. I91 2.

ro. - A biochemical study of the curly-top of sugar beets. U.S. Dept. Agric. Bur. PI. Ind., Bull. 277. 28. I913.

I I. - Oxidases in healthy and in curly dwarf potatoes. Jour. Agric. Research 2:373-403. I9I4.

12. - - The relationship existing between the oxidase activity of plant juices and their hydrogen ion concentration, with a note on the cause of oxidase activity in plant tissue. Jour. Biol. Chem. 28:315-333. I916.

13. - The mode of action of the oxidases. Jour. Biol. Chem. 24:9II02. I9I6.

14. Clark, E. D., The plant oxidases. Diss. Columbia Univ. New York City. pp. I-II3. I9IO.

15. Cook, M. T., and Wilson, G. W., The influence of the tannin content of the host plant on Endothia parasitica and related species. N.J. Exper. Sta. Bull. 29I. 6. I9r6.

r6. Culpepper, C. W., Foster, A. C., and Caldwell, J. S., Some effects of the blackrot fungus, Sphaeropsis malorum, upon the composition of the apple. Jour. Agric. Research 7:17-40. I9I6.

I7. Doвy, Geza, Biochemische Untersuchungen über die Blattrollkrankheit der Kartoffel. Zeitschr. Pflanzenkrank. 21 :204-2II, 40I-403. I9I 2.

I8. Dony-Henault, Octave, Contribution à l'étude méthodique des oxydases. Mém. Bull. Acad. Roy. Belgique 105-I63. I908.

I9. Duggar, B. M., Severy, J. W., and Schmitz, H., Studies in the physiology of the fungi. IV. The growth of certain fungi in plant decoctions. Ann. Mo. Bot. Gard. 4: I66. I9I7.

20. Freiberg, G. W., Studies in the mosaic diseases of plants. Ann. Mo. Bot. Gard. 4:I75-232. I9I 7.

21. Harvey, E. M., Some effects of ethylene on the metabolism of plants. Bот. Gaz. 60:199-207. I9I 5.

22. Hasselbring, Heinrich, Canker of apple trees. Ill. Agric. Exper. Sta. Bull. 70. 225-239. 1902 .

23. Höber, Rudolf, Physikalische Chemie der Zelle und Gewebe. Leipzig und Berlin. I9I4.

24. Kastle, J. H., The oxidases and other oxygen-catalysts concerned in biological oxidations. U.S. Treas. Dept. Hygienic Lab. Bull. 59. I-I64. I9IO.

25. Michaelis, J., Die Wasserstoffionen-konzentration. Berlin. I9I4. 
26. Perrin, J., Mécanisme de l'électricalisation de contact et solutions colloidales. Jour. Chim. Physique. 3:50-1 10. I905.

27. Philip, J. C., Physical chemistry, its bearing on biology and medicine. New York and London. I9ro.

28. REED, G. B., The relation of oxidase reactions to changes in hydrogen ion concentration. Jour. Biol. Chem. 27:299-303. I9I6.

29. REED, H. S., The enzyme activities involved in certain fruit diseases. Va. Agric. Exper. Sta. Rept. I9I I-I9I2. pp. 5I-78.

30. Rose, D. H., Oxidation in healthy and diseased apple bark. Bот. Gaz. $60: 55-65$. I9I 5 .

31. Sorauer, Paul, Die angebliche Kartoffelepidemie, gennant die Blattrollkrankheit. Internat. Phytopath. Dienst (Beigabe, Zeitschr. Pflanzenkrank.). 33-59. 1908.

32. - Die neueren Untersuchungen von Quanjer über die Ursache der Blattrollkrankheit der Kartoffel und der Sorauer'sche Standpunkt. Zeitschr. Pflanzenkrank. 23:244-253. I913.

33. Trillat, O., Sur le rôle d'oxydases que peuvent jouer les sels manganeux ex présence d'un colloide. Compt. Rend. 138:274-277. 1904.

34. Wiley, H. W., Official and provisional methods of analysis. Association of Official Agricultural Chemists. As compiled by the committee on the revision of methods. U.S. Dept. Agric. Bur. Chem. Bull. I07 (rev). I908.

35. Woons, A. F., Observations on the mosaic disease of tobacco. U.S. Dept. Agric. Bur. Pl. Ind., Bull. I8. I7-22. 1902. 


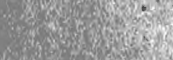

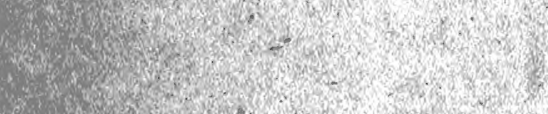

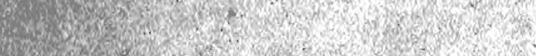

35

50.

(2)

(a)

$\cos 20$

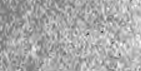

(5)

(2)

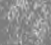

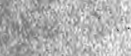

2.)

2.

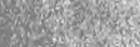

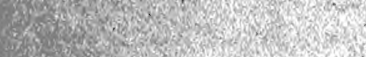

1.

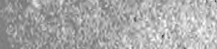

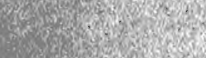

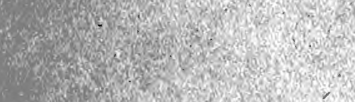

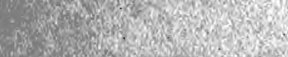

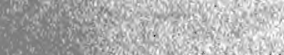

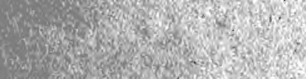

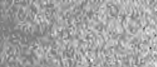

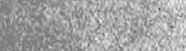

$x_{1}=0$

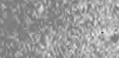

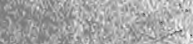

is.

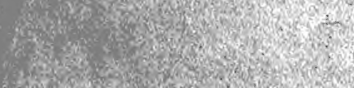

H.

W.

2.

2.

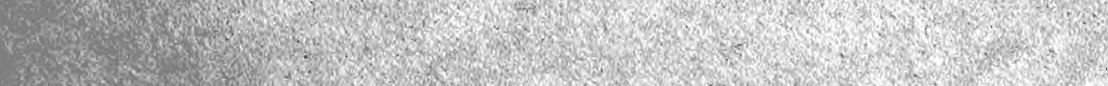
W.

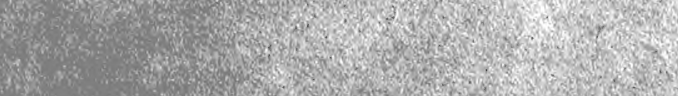

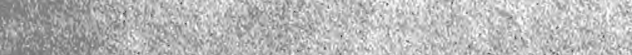

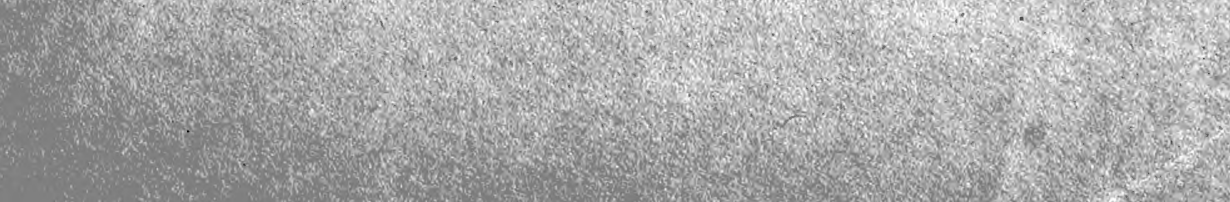


